\title{
Medical therapy of stricturing Crohn's disease: what the gut can learn from other organs - a systematic review
}

\author{
Dominik Bettenworth ${ }^{1+}$ and Florian Rieder ${ }^{2,3^{*}+}$
}

\begin{abstract}
Crohn's disease (CD) is a chronic remitting and relapsing disease. Fibrostenosing complications such as intestinal strictures, stenosis and ultimately obstruction are some of its most common long-term complications. Despite recent advances in the pathophysiological understanding of $C D$ and a significant improvement of anti-inflammatory therapeutics, medical therapy for stricturing CD is still inadequate. No specific anti-fibrotic therapy exists and the incidence rate of strictures has essentially remained unchanged. Therefore, the current therapy of established fibrotic strictures comprises mainly endoscopic dilation as well as surgical approaches. However, these treatment options are associated with major complications as well as high recurrence rates. Thus, a specific anti-fibrotic therapy for CD is urgently needed. Importantly, there is now a growing body of evidence for prevention as well as effective medical treatment of fibrotic diseases of other organs such as the skin, lung, kidney and liver. In face of the similarity of molecular mechanisms of fibrogenesis across these organs, translation of therapeutic approaches from other fibrotic diseases to the intestine appears to be a promising treatment strategy. In particular transforming growth factor beta (TGF- $\beta$ ) neutralization, selective tyrosine kinase inhibitors, blockade of components of the renin-angiotensin system, IL-13 inhibitors and mammalian target of rapamycin (mTOR) inhibitors have emerged as potential drug candidates for anti-fibrotic therapy and may retard progression or even reverse established intestinal fibrosis. However, major challenges have to be overcome in the translation of novel anti-fibrotics into intestinal fibrosis therapy, such as the development of appropriate biomarkers that predict the development and accurately monitor therapeutic responses. Future clinical studies are a prerequisite to evaluate the optimal timing for anti-fibrotic treatment approaches, to elucidate the best routes of application, and to evaluate the potential of drug candidates to reach the ultimate goal: the prevention or reversal of established fibrosis and strictures in CD patients.
\end{abstract}

Keywords: Crohn's disease, Intestinal fibrosis, Organ fibrosis, Anti-fibrotic agents

\section{Methods}

\section{Literature search and data selection}

A comprehensive literature search was performed to assess all relevant citations found in Embase, Medline (service of the US National Library of Medicine (NLM) and the National Institutes of Health (NIH)) and the Cochrane Library for the following key words: ('Crohn's disease (CD') OR 'Crohn's' AND ('stricture' OR 'fibrosis'), ('kidney' OR 'liver'

\footnotetext{
* Correspondence: riederf@ccf.org

${ }^{\dagger}$ Equal contributors

${ }^{2}$ Department of Gastroenterology and Hepatology, Digestive Disease Institute, Cleveland Clinic Foundation, Cleveland, OH, USA

${ }^{3}$ Department of Pathobiology, Lerner Research Institute, NC22, Cleveland

Clinic Foundation, 9500 Euclid Avenue, Cleveland, OH 44195, USA

Full list of author information is available at the end of the article
}

OR 'skin' OR 'lung' OR 'systemic nephrogenic' AND 'fibrosis' OR 'anti-fibrotic therapy'). Additionally, references of cited original articles and reviews were further assessed for relevant work. The search included studies between 1960 and 2013. These data together with the authors' personal experience in the field represent the basis of this review.

\section{Introduction}

Crohn's disease (CD) is a chronic remitting and relapsing disease [1]. During acute flares, CD patients may present with mainly inflammation driven symptoms such as diarrhea, abdominal pain and weight loss [2]. However, over the long-term, the naturally progressive disease course often culminates in stricture formation. 
For example, around $40 \%$ of CD patients with ileal disease develop clinically apparent strictures [3]. Strictures may be subdivided into fibrotic and inflammatory as well as mixed forms [4]. Accordingly, strictures including inflammatory alterations might benefit from anti-inflammatory therapy through a reduction of the inflammation-mediated edema [5]. During the last two decades, the therapeutic armamentarium for CD has expanded significantly, especially with the use of antitumor necrosis factor alpha (TNF- $\alpha$ )-based strategies that can lead to sustained clinical response rates in a substantial proportion of CD patients [6-8]. The success of anti-TNF antibodies fueled the hope for altering the natural course of CD. Most recent epidemiological data, however, revealed that despite the establishment of early immunosuppressive therapy in CD patients with an increased risk of disabling disease, the frequency of fibrostenosing complications did not significantly change [9]. Thus, a specific anti-fibrotic therapy for stricturing complications in CD patients is needed. Despite recent advances in the pathophysiological understanding of intestinal fibrosis in CD $[10,11]$ and in contrast to fibrotic complications in other organs, no specific anti-fibrotic drugs for intestinal strictures are currently available, and all existing therapies used in clinically apparent CD-associated stenosis are the same that are prescribed for active luminal disease. The same holds true for the treatment of penetrating $\mathrm{CD}$, another inflammatory bowel disease (IBD)-associated complication that is linked to impaired intestinal remodeling and healing. Available drugs for the treatment of fibrostenosing or penetrating IBD are depicted in Figure 1. Consequently, the therapy of choice for fibrostenosing $\mathrm{CD}$, in conjunction with purely anti-inflammatory therapy, comprises endoscopic dilation (ED) procedures as well as surgical approaches, with all their associated limitations and morbidity [12-14]. A significant number of patients have to undergo multiple surgeries, with the subsequent risk of developing intestinal failure. In general, isolated strictures with a length of $4 \mathrm{~cm}$ or less [12] which are devoid of ulcers [15] and are accessible by colonoscopy [16] or double-balloon enteroscopy [17] qualify for ED. Although ED procedures for stricturing CD are usually technically successful, more than one third of patients will still undergo surgery within the next years due to insufficient response to ED [12-14]. In addition, major complications such as bowel perforation, bleeding or infection are reported in a range of 2 to $5 \%[12,18]$. In those $\mathrm{CD}$ patients where endoscopic stricture therapy is technically not feasible or not indicated, surgical approaches including resection and strictureplasty are recommended. While repeated surgical bowel resections bear the risk for induction of deficiencies in gastrointestinal functions and ultimately may manifest short bowel syndrome and intestinal failure, strictureplasty can treat intestinal obstruction without reducing intestinal length [10]. Here, the incidence of major complications including anastomotic leakage, abscess, fistula or sepsis is present in about 6\% [19]. The recurrence rates differ between various forms of strictureplasty from 23 to $41 \%$

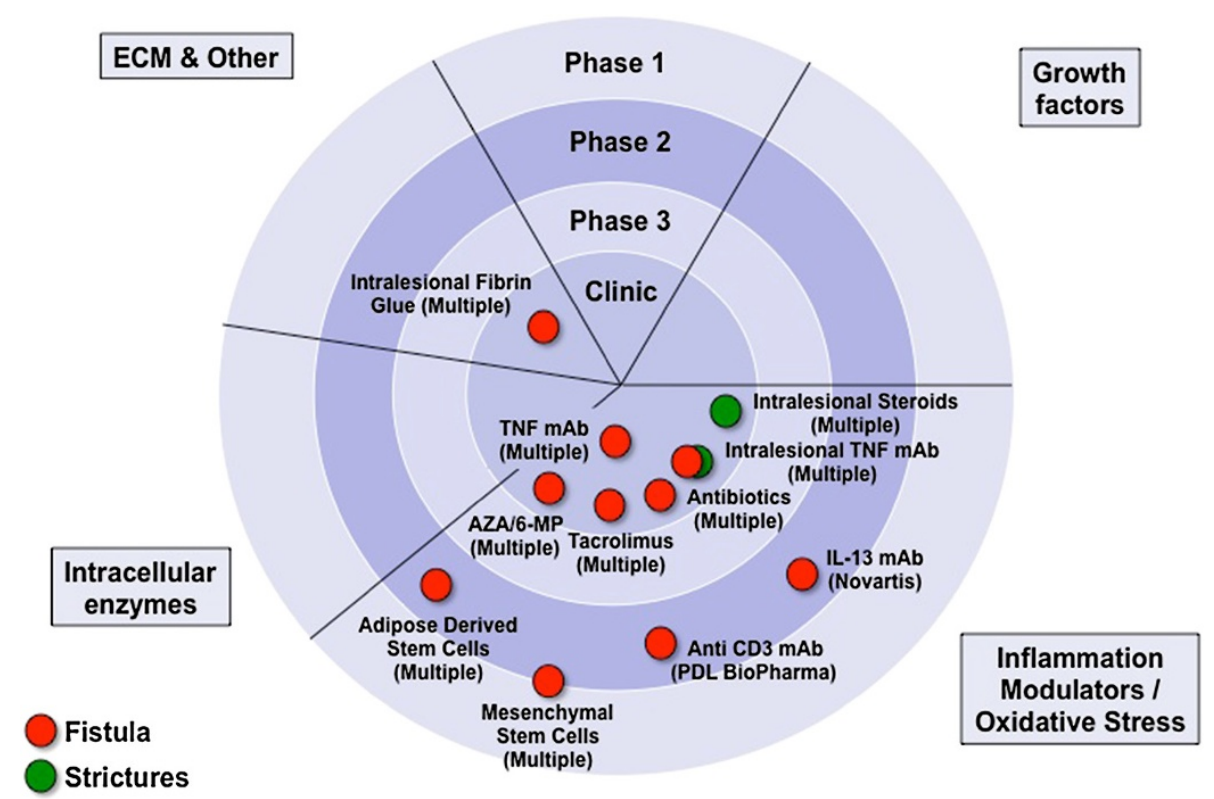

Figure 1 Therapeutic strategies to modify wound healing in Crohn's disease. Currently available therapies for stricturing or fistulizing CD are depicted. Data derived from Embase, Medline and ClinicalTrials.gov. 6-MP, 6-mercaptopurine; AZA, azathioprine; CD, Crohn's disease; ECM, extracellular matrix; IL, interleukin; mAb, monoclonal antibody; TNF, tumor necrosis factor. 
[20-22]. To date, no head to head comparison between ED and strictureplasty has been performed yet. Taken together, the insufficient therapeutic impact of currently available anti-inflammatory drugs on stricture prevention and treatment, the complications associated with ED or surgical treatment approaches associated with high socioeconomic burden [23] as well as the high recurrence rates of stricturing $\mathrm{CD}$ after procedures demand the development and evaluation of specific anti-fibrotic agents for stricturing CD.

\section{Review}

\section{A basic overview of mechanisms of intestinal fibrosis}

Fibrosis is defined as the accumulation of collagen-rich extracellular matrix (ECM) in response to tissue damage and is a common complication of multiple chronic diseases [24]. Repetitive or persistent injury of the intestinal epithelium and subsequently deeper layers of the intestinal wall may initiate, perpetuate or maintain progressive fibrosis [24]. With regard to the gastrointestinal tract, acute, short-lived epithelial damage may occur as a consequence of peptic ulcers, infectious enteritis or mild diverticulitis, leading to a full restitution of tissue structure. In contrast, in $\mathrm{CD}$, the gastrointestinal mucosa is exposed to chronic remitting or continuous pro-inflammatory and environmental stimuli. Pleiotropic mechanisms are activated like cellular stress, increased production of inflammatory cytokines and chemokines such as IL-13 or IL-17 $[25,26]$ and growth factors, such as transforming growth factor beta 1 (TGF- $\beta 1$ ) [27], insulin-like growth factor (IGF) [28], platelet-derived growth factor (PDGF) [29] and basic fibroblast growth factor (bFGF) [30]. These mediators crucially contribute to morphological and functional alterations within the bowel wall that may finally culminate in stricture formation and loss of physiological gut functions $[31,32]$. In the murine model of 2,4,6-trinitrobenzene sulfonic acid (TNBS)-induced colitis, inhibition of IL-13 signaling by administration of small interfering RNA targeting the IL-13- $\alpha 2$ receptor attenuated inflammation-associated intestinal fibrosis [25]. This observation was corroborated by work from the same group, indicating that TGF- $\beta 1$ secretion by macrophages was increased upon IL-13 stimulation in vitro and in vivo [33]. Contractility of isolated intestinal smooth muscle from CD patients was enhanced after pre-stimulation with IL-13 [34]. Additionally, increased IL-13 transcripts were detected in muscle extracts from intestinal samples of fibrotic CD patients compared to samples from non-inflamed areas, which results in inhibition of fibroblast matrix metalloproteinase (MMP) synthesis [35]. In contrary to these findings, there was no difference in IL-13 production in mucosal explants and lamina propria mononuclear cells between patients with stricturing $\mathrm{CD}$ and control subjects in a different study [36].
IL-17A was found to possess pro-fibrotic activity in various cell types including cardiac fibroblasts [37], hepatic stellate cells [38], skin fibroblasts [39] and lung epithelial cells [40]. In addition, IL-17E was shown to increase collagen production in lung fibroblasts [41]. Consistent with a role of IL-17 in fibrosis IL-17 tissue levels were increased in a murine model of intestinal fibrosis [26]. In human fibrotic CD, IL-17A, but not IL-17E, was overexpressed within tissue samples from $C D$ strictures as compared to nonstrictured CD areas and healthy gut. IL-17 secretion from cultured intestinal explants from strictured $C D$ patients was significantly increased as compared to non-strictured CD samples. Moreover, myofibroblasts from CD strictures, expressing the IL-17A receptor, generated more collagen and tissue inhibitor of metalloproteinase 1 (TIMP-1) and revealed inhibitory effects on myofibroblast migration [42]. In a clinical trial of patients with inflammatory $C D$, however, blockade of anti-IL-17A by administration of the anti-IL-17A antibody secukinumab failed to improve disease activity, was associated with a high rate of serious adverse events and had to be stopped prematurely since predefined criteria for futility were met [43], indicating that further studies are necessary before using anti-IL-17-based strategies in the therapy of intestinal fibrosis.

The core mediator in various organs for both, the initiation as well as the maintenance of fibrosis is TGF- $\beta$ [44]. This growth factor is produced by a vast majority of cells and organs in mammals and is stored in large amounts extracellularly through chemical cross-links to the ECM [45]. The TGF- $\beta /$ Smad signaling pathway appears pivotal for the development of fibrosis [44]. Canonical intracellular signal transduction is mediated by Smad2/3 phosphorylation by TGF- $\beta$ receptor I kinase leading to binding of Smad4. This complex translocates into the nucleus and induces TGF- $\beta$-specific pro-fibrotic gene expression [46]. Inhibitory members of the Smad family such as Smad6/7 block the phosphorylation of Smad $2 / 3$ via competition with the TGF- $\beta$ receptor I kinase $[47,48]$.

In addition to the above mentioned mediators, the imbalance of MMPs and TIMPs, which are physiologically involved in maintaining a state of 'healthy' remodeling and restitution, can aggravate structural changes of the bowel wall $[48,49]$.

Restoring the integrity of the intestinal barrier, culminating in epithelial wound closure may help to resolute and regress fibrosis, since continuous barrier defects appear to be one potential trigger for chronic inflammation promoting pro-fibrotic alterations. To this aim ECMproducing mesenchymal cells are recruited. These cells may migrate from neighboring tissue [50], originate from circulating mesenchymal cell precursors or bone marrow stem cell-derived mesenchymal cells [51], arise 
by proliferation from existing mesenchymal cells [30] or result from epithelial- or endothelial-mesenchymal transition (EMT and EndoMT, respectively) [52]. Recently, the intestinal microbiota has been identified as a key profibrotic factor, as suggested by several lines of evidence: 1) Ligands to Toll-like receptor 4 (TLR4) (predominantly from gram-negative bacteria) or TLR2 (predominantly from gram-positive bacteria) activate NF- $\kappa \mathrm{B}$, resulting in cytokine and chemokine secretion by intestinal mesenchymal cells [53]. 2) In several experimental colitis models, microbes initiate or perpetuate gut inflammation and fibrosis, such as in SAMP1/YitFc mice, the IL-10 knock out mice, TNBS and peptidoglycan-polysaccharide (PG-PS)-induced colitis [54]. 3) In humans, gene variants that affect innate immunity, located in or near genes involved in bacterial recognition and processing, are genetically associated to IBD or CD as well as complicated CD courses [55]. 4) Finally, circulating antibodies against microbial components are commonly found in IBD patients and are believed to arise from an immune response towards the luminal microbiota. These antibodies are qualitatively and quantitatively associated with and predictive of a more complicated disease phenotype including fibrostenosis [50,56-58].

Beside chronic inflammation as a major driver of intestinal fibrosis, inflammation-independent mechanisms deserve closer attention. In particular, activated mesenchymal cells, also referred to as disease-activated myofibroblasts, produce and secrete high levels of several collagen types, such as type I, III and V [59-61] and ECM compounds, such as fibronectin or tenascin $C[62,63]$ which get deposited, linked and subsequently form matrix networks that can lead to increased tissue stiffness [64]. Stiffness in itself in the absence of inflammation activates further mesenchymal cells in the form of a positive feedback loop [64]. The ability of myofibroblasts to contract might further increase the luminal narrowing of the intestine and contraction can be induced by factors other than inflammatory mediators [65]. Interestingly, latent matrix-bound TGF- $\beta 1$ can be activated by mesenchymal cells' traction forces, pulling against a mechanically resistant ECM. This leads to a conformation change of the latency-associated peptide liberating the active TGF- $\beta 1$ [66].

In summary, despite different physiological functions and unique features of the human gut, such as the high load of microbial components, intestinal fibrosis shares pathological core features with fibrosis of other organs, such as the lung, kidney, skin or liver [24]. Consequently, antifibrotic agents with proven efficacy in fibrotic disease of these organs may represent promising candidates for stricturing $\mathrm{CD}$ and will be discussed in the following section.

\section{Anti-fibrotic therapeutic approaches in other organs} Commonly used drugs for the anti-inflammatory therapy of CD have been observed to possess at least minor anti- fibrotic properties in other organs. For example, corticosteroids were found to decrease pro-collagen expression in vivo and in vitro [67] as well as to inhibit collagenase activity [68]. Corticosteroids show some effect in retroperitoneal fibrosis [69], systemic sclerosis [70] and idiopathic pulmonary fibrosis (IPF) [71]. In contrast, human intestinal myofibroblasts respond to corticosteroids with enhanced pro-collagen expression upon dexamethasone stimulation [72]. In stricturing CD, small case series report variable therapeutic success rates of intralesional steroid injection [73]. The long-term systemic administration of corticosteroids in $\mathrm{CD}$, however, is obsolete due to severe and pleiotropic side effects. Azathioprine, one of most commonly prescribed immunosuppressive drugs for maintenance of remission in $\mathrm{CD}$ patients, is beneficial in the treatment of retroperitoneal fibrosis [74] and fibrotic pulmonary disease [75,76]. In CD patients, azathioprine may delay postoperative, fibrotic complications [77], however, the early use of immunosuppressive treatment regimens does not reduce the occurrence of intestinal strictures and frequency of surgical interventions in the long-term $[9,78]$. TNF- $\alpha$ is a critical cytokine in the pathogenesis of IBD and to date four anti-TNF antibodies have shown clinical efficacy as anti-inflammatory agents [79-82] and are available for clinical use. Several reports from liver fibrosis [83], pulmonary fibrosis [84] and systemic sclerosis [85] suggest an anti-fibrotic effect of anti-TNF treatment. This could be explained by TNF- $\alpha$-mediated myofibroblast activation, increased collagen production and TIMP-1 expression as well as inhibition of MMP-2 activity and collagen degradation [86]. In contrast, human intestinal myofibroblasts from CD patients show increased expression of TIMP-1 and decreased collagen production upon exposure to infliximab [87]. After initially conflicting data in patients with CD with a possible pro-fibrotic effect of anti-TNF therapy in vivo, recent data revealed no link between antiTNF administration with intestinal stricture formation [88]. Information derived from a small retrospective study points towards at least a partial amelioration of stricture formation with anti-TNF therapy [89] and anti-TNF treatment may delay the time to surgery in $\mathrm{CD}[90]$.

In daily clinical practice, most $C D$ patients present with established strictures, representing the end-stage of the fibrotic process, and most clinicians see this scenario as an inevitable progression to a likely surgical intervention. This does not have to be so, as the theoretical and practical feasibility to stop or even reverse intestinal fibrosis is supported by the observation that tissue alterations in experimental models of intestinal fibrosis disappear after elimination of the pro-fibrotic stimulus [54]. No therapeutic medical strategy for pre-existing intestinal strictures exists at the moment, but this clinical scenario could greatly improve by looking at existing knowledge derived from other organ systems. 
Anti-fibrotic strategies used in the kidney, lung, liver, heart or skin can be grouped into strategies modulating growth factors, inflammation or oxidative stress, intracellular enzymes, and ECM production or assembly (Figure 2). We herein provide a summary of currently available experimental anti-fibrotics that have been tested for indications outside of the intestine. We selected promising mechanisms and agents that could be applicable to stricture therapy of CD in the near future and describe them in greater detail.

\section{Growth factors}

Feasibility of TGF- $\beta 1$ blockade to treat fibrotic diseases has been shown in IPF. In this condition, TGF- $\beta$ is driving fibrotic alterations and epithelium-dependent fibroblast activation [44]. In murine models of IPF, antagonizing TGF- $\beta$ action via T $\beta$-RII (as a ligand decoy), P144, an inhibitor of TGF- $\beta$ activity, or P17, an anti-TGF- $\beta$ peptide, resulted in potent anti-fibrotic effects [91-93]. In human IPF patients, two phase III trials have shown that treatment with pirfenidone, an agent inhibiting TGF- $\beta$ activity and p38 mitogen-activated protein kinase (MAPK) signaling, improved pulmonary function [94,95]. Pirfenidone is expected to be approved for IPF in Europe soon [96]. Another example for the potential of anti-TGF- $\beta$-based strategies is scleroderma, a disease characterized by enhanced expression of T $\beta R I$ and T $\beta R I I$ in fibroblasts leading to increased collagen I production and ECM deposition in the skin and internal organs [97]. Topical treatment with
P144 has shown efficacy in patients with systemic sclerosis, and multiple trials with this agent are currently ongoing. Fresolimumab (GC1008) is a humanized antibody targeting anti-TGF- $\beta 1,2$ and 3 and was recently evaluated in a phase I trial in patients with treatment-resistant primary focal segmental glomerulosclerosis [98]. The humanized $\alpha \mathrm{V} \beta 6$ integrin-blocking antibody STX-100, which inhibits the activation of latent TGF- $\beta$ on epithelial cells, is currently being examined in a phase II trial in IPF patients [24,99]. Comparable results have been reported from kidney fibrosis: preclinical in vitro and in vivo studies indicate an anti-fibrotic activity using anti-TGF- $\beta$ antibodies, soluble TGF- $\beta$ receptor, blockade of TGF- $\beta$ activation by decorin, a small-molecule inhibitor of TGF- $\beta$ receptors [100], administration of inhibitory protein Smad7 [101] and thrombospondin-1 (THBS-1) blocking agent inhibiting TGF- $\beta$ activation [102]. In human patients with focal segmental glomerulosclerosis, a phase I trial with fresolimumab revealed promising results [98]. Moreover, hepatic growth factor, acting as an inhibitor of Smad2/3 translocation in fibroblasts [103] was observed to mediate anti-fibrotic effects in experimental models of renal and liver fibrosis but was also associated with an increased risk of hepatocellular carcinoma [104]. Substrate specificity of therapeutics needs to be taken into consideration as well. In an experimental model of scleroderma, blocking activin receptor-like kinase 5 (ALK5), which is involved in phosphorylation of $\operatorname{Smad} 2 / 3$, leads to decreased fibroblast activation. However, ALK5 blockade in clinical

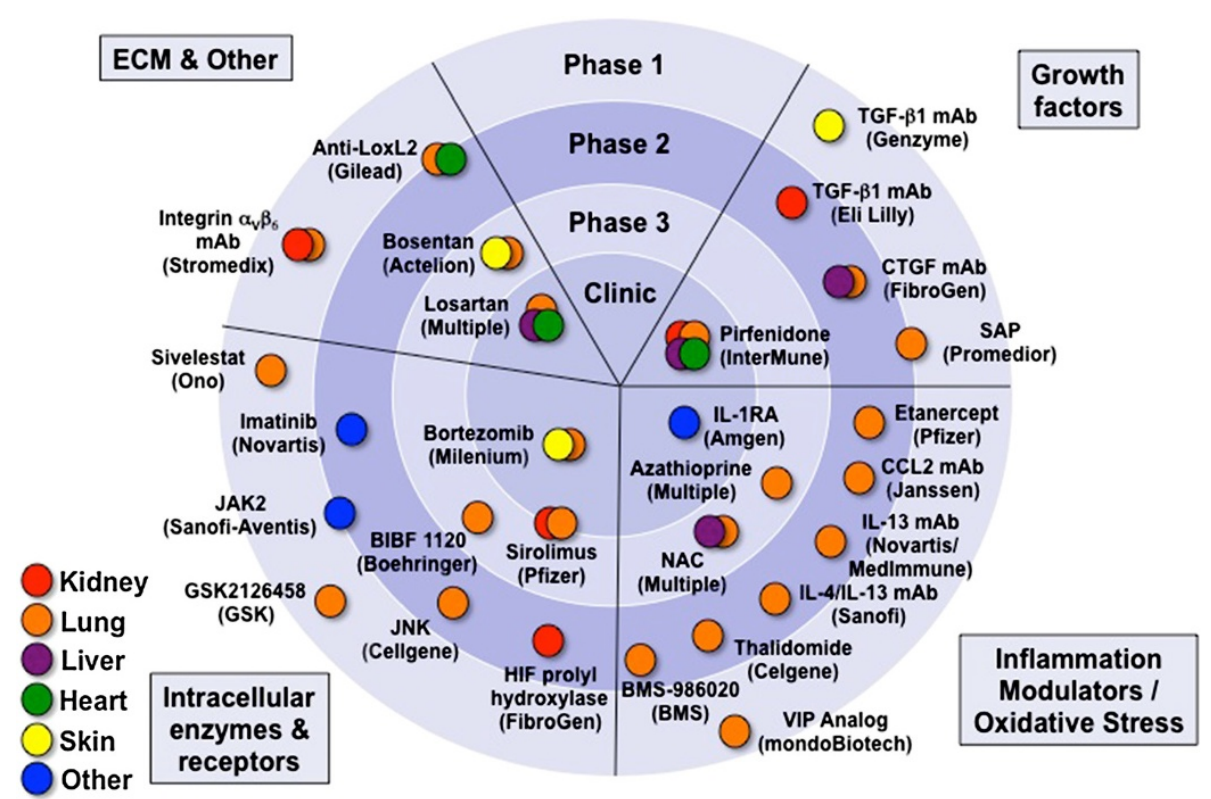

Figure 2 Pipeline for therapeutic strategies to alter and improve fibrosis in organs other than the intestine. Each color represents a particular organ. Agents are classified based on their mode of action. Data derived from Embase, Medline and ClinicalTrials.gov. CCL2, chemokine ligand 2; CTGF, connective tissue growth factor; ECM, extracellular matrix; HIF, hypoxia inducible factor; IL, interleukin; JAK, janus kinase; JNK, c-Jun N-terminal kinase; mAb, monoclonal antibody; SAP, serum amyloid P component; TGF- $\beta$, transforming growth factor beta; VIP, vasoactive intestinal peptide. 
trials was associated with adverse events due to crossreactivity with other kinase inhibitors [105].

In addition to the Smad-signaling cascade, non-Smad pathways comprising TGF- $\beta 1$ activated MAPKs and several tyrosine kinases have been targeted for anti-fibrotic actions. For example, c-Abelson (c-Abl), a component of the Bcr-Abl oncogene, can be effectively blocked by selective tyrosine kinase inhibitors such as imatinib. This agent inhibits PDGF as well and thus potentially regulates fibroblast proliferation and transformation [106]. Despite promising results from in vitro and in vivo studies, to date limited experience with tyrosine kinases in human fibrotic diseases is available $[107,108]$. Of note, novel tyrosine kinase inhibitors such as nilotinib and dasatinib mediate dose-dependent decreases in ECM production and reveal even greater efficacy as compared to that of imatinib [109], while being well tolerated by the patients [110]. In contrast to TGF- $\beta 1$, other members of the TGF family such as TGF- $\beta 3$ possess antifibrotic properties. Avotermin is a recombinant bioactive human TGF- $\beta 3$ that has been tested for treatment of dermal scars and significantly reduces the scar size by intradermal injection therapy [111]. In addition, further growth factors such as serum amyloid P (SAP) have been proven effective in experimental models [112,113] of fibrosis and have already entered phase I clinical trials in human patients [114].

The scientific rationale to target TGF- $\beta$ signaling in stricturing $\mathrm{CD}$ comes from in vitro as well as in vivo observations. For example, intestinal TGF- $\beta$ overexpression in mice leads to colonic fibrosis and obstruction [27], while disruption of the TGF- $\beta /$ Smad signaling cascade protects animals from intestinal fibrosis [115]. In human tissue samples from colonic CD strictures, TGF- $\beta$ and its receptors as well as pSmad $2 / 3$ expression are increased, while Smad7 expression was significantly reduced [116]. Although targeting TGF- $\beta$ signaling for fibrotic diseases has a strong scientific rationale, it has to be taken into account that this growth factor is not only crucially involved in fibrogenesis but additionally functions as a key regulator of cellular processes including differentiation, proliferation, transformation, tumor suppression as well as immunoregulation and its actions may be context-dependent $[96,117]$. For example, TGF- $\beta 1$-deficient mice develop severe multiorgan inflammation and expire by 5 weeks of age $[118,119]$. This outcome occurs even under germ-free conditions [120] and is mediated by CD4+ T cells [121]. Similarly, targeted deletion of Smad2 and Smad4 is associated with early death in mice [122,123]. Furthermore, administration of metelimumab, a monoclonal antibody against TFG- $\beta 1$, in human systemic sclerosis patients was associated with significantly more serious adverse events than placebo treatment including musculoskeletal pain, progression of skin involvement and death [124]. Possible side effects during
anti-TGF- $\beta$ therapy would have to be carefully monitored, in particular in case of pre-existing inflammation. Therefore, neutralizing TGF- $\beta 1$ in vivo, as an anti-fibrotic approach in $\mathrm{CD}$ may be highly problematic, as this may actually lead to disease exacerbation given the potent anti-inflammatory and immunoregulatory properties of this cytokine.

\section{HMG-CoA reductase inhibitors}

HMG-CoA reductase inhibitors were developed with the intention to decrease cholesterol levels. More recently, they were found to mediate anti-inflammatory as well as anti-fibrotic effects in vitro [125], including decreased proliferation of mesangial cells, lower fibronectin as well as type IV collagen expression and decreased secretion of TGF- $\beta 1$ and connective tissue growth factor (CTGF) [126-128]. Corroborating these in vitro findings, HMGCoA reductase inhibitors revealed various anti-fibrotic effects in murine models of nephropathy and fibrosis $[126,127]$. In CD patients, HMG-CoA reductase inhibitor atorvastatin was shown to mediate anti-inflammatory effects such as inhibition of $\mathrm{T}$ cell recruitment via reduced CXCL10 levels [129] and reduce surrogate inflammatory markers such as calprotectin, C-reactive protein and TNF$\alpha$ expression [130]. Furthermore, it was demonstrated that simvastatin reduced TGF- $\beta 1$ expression in human fibroblasts by inhibition of Smad3 phosphorylation [131] leading, together with induced apoptosis in fibroblast and myofibroblasts, to a significant amelioration of experimental fibrosis [132]. In addition, mesenchymal cells isolated from patients with radiation-induced intestinal fibrosis respond to pravastatin treatment with significantly decreased production of fibronectin and type-1 collagen through Rho-/ROCK-dependent reduction of CTGF expression [133]. Nevertheless, the exact antifibrotic potential of statin treatment in stricturing $C D$ still needs to be defined by the use of hard clinical endpoints, but this drug class has an already established safety profile for routine clinical use and could serve as a potential anti-fibrotic treatment approach.

\section{Renin-angiotensin system (RAS) modulators}

Angiotensin II (AT II) is the major mediator of the renin-angiotensin system (RAS). AT II may increase ECM accumulation through plasminogen activator inhibitor-1mediated decrease of MMPs and enhance TGF- $\beta 1$ production in cardiac and renal fibrosis $[134,135]$. The impact of AT II can also be observed in liver fibrosis. In hepatic stellate cells, AT II induces contraction and proliferation accompanied by increased collagen and TGF- $\beta$ expression [136]. Accordingly, progression of liver fibrosis in hepatitis $\mathrm{C}$ virus positive patients is significantly decreased after treatment with angiotensin-converting enzyme inhibitors [137]. AT II is crucially involved in the manifestations of 
renal fibrosis by induction of pro-fibrotic effector molecules and EMT resulting in enhanced ECM production [138], and inhibition of AT II using angiotensin-converting enzyme (ACE) inhibitors or blocking agents towards the AT I receptor has emerged as a therapeutic approach to slow down renal disease progression [139] and revealed antifibrotic actions in the lung, heart and liver [140-143]. Interestingly, all components of the RAS have been detected in the human colonic mucosa [144] and AT II is increased in the mucosa of CD patients [145]. In vivo administration of the ACE inhibitor enalaprilate has been proven to reduce weight loss and histological damage in murine dextran sulfate sodium (DSS)-induced colitis [146]. ACE inhibitor treatment was also effective in spontaneous colitis of IL-10deficient mice [147] and this finding has been confirmed by other studies [148,149].

Of note, through its AT1 receptor, AT II enhances the expression of CTGF, and administration of AT II inhibitors and AT1 receptor antagonists significantly ameliorates or reverses fibrotic alterations in experimental colitis reflected by reduced collagen amounts and TGF$\beta 1$ mRNA levels [150,151]. Existing preclinical data in IBD combined with clinical trials from the liver and kidney make RAS modulation a promising future approach for CD-associated fibrosis.

\section{Inflammation modulators}

Pro-inflammatory cytokines contributing to the pathogenesis of IBD could also be involved in the development of intestinal fibrosis in CD. For example, IL-1 modulates myofibroblast activation, chemokine production, MMP secretion [152] and is involved in EMT induction [153]. IL-6 is known to regulate TGF- $\beta$ and TGF- $\beta$ R2 expression as well as fibroblast proliferation $[154,155]$ and is strongly upregulated in serum and tissue samples from CD patients [156]. IL-4 and IL-13 represent pivotal mediators of immune activation and $\mathrm{T}$ helper cell 2 responses are crucially involved in the development of intestinal fibrosis in vivo. IL-13 mediates, through binding to its IL-13R $\alpha$, an increased production of TGF- $\beta$ and is a key player in the initiation of fibrotic alterations in the intestine [25]. Confirmatively, antagonism of IL-13 is effective to prevent fibrosis development in experimental colitis $[33,157]$. In addition, several IL13 antibodies such as lebrikizumab, tralokinumab and QAX576 as well as the anti-TNF antibody etanercept and the immunomodulatory drug thalidomide are currently being evaluated for their anti-fibrotic potency in liver fibrosis and pulmonary fibrosis [24,158-160].

The process of inflammation and fibrosis are likely to be intertwined through angiogenesis and lymphangiogenesis. Increased levels of factors implicated in angiogenesis have been documented in IBD patients, such as vascular endothelial growth factor A (VEGF-A) [161]. At a cellular level, PDGF increases proliferation and migration of fibroblasts and myofibroblasts [46]. In the human intestine, PDGF facilitates ECM deposition and is upregulated in inflamed colonic tissue specimen of CD patients [29]. Experience with blocking these agents in other fibrotic diseases exist. In a phase II trial, combined blockade of VEGF, PDGF and bFGF by the indolinone derivative BIBF 1120 tends to decrease the development of human IPF [162]. Critical for the future use of inflammation modulators in the therapy of CD-associated fibrosis will be the quality, quantity and the timing of the approach because all of the above mediators act at different times throughout the disease course, in differing combinations and quantities [163]. Additionally, all of the above molecules interact with each other and blocking a single cytokine at a specific time might not be sufficient for effective anti-fibrotic therapy.

\section{Extracellular matrix modulators}

The imbalance between deposition and degradation of ECM in fibrotic disease is a logical target for anti-fibrotic treatment approaches. Stimulation of MMPs as central regulators of ECM disassembly were expected to reverse fibrotic alterations, however, clinical studies in patients with nephrosclerosis failed to show efficacy [164]. Likewise, depletion of TIMP should decrease fibrotic changes, but no amelioration of renal fibrosis was observed following TIMP inhibition in mice [165]. With regard to the intestine, there is growing evidence for MMPs as a regulator of intestinal barrier function and mucosal defense [166], indicating pleiotropic functions of this molecular group in addition to purely matrix regulation. For example, serum MMP-9 levels correlate with disease activity in pediatric CD patients [167] and may be used as a biomarker to follow the course of disease in adult CD patients as well $[168,169]$. Colonic tissue expression of MMP-1, MMP-2, MMP-3 and MMP-9 was significantly increased in samples from inflamed mucosa as compared to non-inflamed mucosal samples [170]. Increased MMP-9 expression in inflamed tissue colonic specimen from CD patients seems to be associated with decreased likelihood of disease recurrence [171]. Finally, in mucosa specimen overlaying colonic strictures in CD patients, MMP-3 and MMP-12 expression was significantly reduced [116]. Thus, MMPs need to be further and carefully investigated as possible targets for anti-fibrotic treatment in as well as outside of the intestine and are not yet ready for prime time.

\section{Intracellular enzymes and receptors}

The mammalian target of rapamycin (mTOR) protein is a serine/threonine protein kinase that consists of several complexes among which mTOR complex 1 regulates protein synthesis, proliferation as well as fibrotic actions [46]. mTOR inhibitors possess direct anti-fibrotic properties by 
decreasing fibroblast and myofibroblast numbers and by reducing pro-fibrotic cytokine expression, including IL-4, IL6, IL-13, IL-17, TGF- $\beta 1$ as well as type I and III collagen $[172,173]$. Efficacy of mTOR inhibitors have been demonstrated in numerous fibrotic disorders of the skin, lung, kidney and liver [46]. With regard to CD, a randomized, double-blind clinical trial found that everolimus was as effective as azathioprine to achieve steroid-free remission in 138 patients with active CD [174]. Additionally, there are two case reports indicating that mTOR inhibitors sirolimus and everolimus are able to induce remission in refractory CD $[175,176]$. Given the fact that mTOR inhibitors possess anti-fibrotic as well as immunosuppressive effects, this class of drug appears to be promising for intestinal fibrosis therapy, however, the definitive therapeutic potential for intestinal fibrosis remains to be defined yet.

Peroxisome proliferator-activated receptor gamma (PPAR- $\gamma$ ) is a nuclear receptor that modulates gene expression and is involved in various physiological and pathological processes including inflammation and fibrosis [177]. After stimulation with specific ligands, PPAR- $\gamma$ directly antagonizes Smad3 or reduces CTGF expression [178]. PPAR- $\gamma$ agonists are able to improve experimental fibrosis, while PPAR- $\gamma$ selective antagonists abolish anti-fibrotic actions $[179,180]$. Given the fact that CTGF is a key downstream effector of TGF- $\beta$ on connective tissue cells, FG3019, a humanized antibody targeting CTGF, has been developed and successfully passed phase I trials in several fibrotic disorders and recently entered phase II studies [24]. In the human intestine, PPAR- $\gamma$ has been detected in the colonic mucosa and has been identified as a mediator of established anti-inflammatory drugs such as 5-ASA $[177,181]$. The future role of PPAR- $\gamma$ agonists as a possible target for anti-fibrotic treatment in stricturing $\mathrm{CD}$ is promising, given the combined action against inflammation and fibrosis and its well-defined mechanism of action. Furthermore, other drug candidates such as endothelin A receptor antagonist bosentan have shown promising results in patients with IPF and renal interstitial fibrosis and deserves further investigation [182,183].

A summary of compounds used as anti-fibrotic therapies in other organs and their mode of action is depicted in Figure 3. Anti-fibrotic clinical trials of major interest are shown in Table 1.

\section{Challenges and future outlook}

The most efficient anti-fibrotic treatment approach still remains the elimination of the primary cause of intestinal injury, which would mean nothing less than curing CD. However, since a magic bullet for CD is not and will most likely not be available in the near future, clinical evaluation and optimization of anti-fibrotic drug candidates for stricturing $\mathrm{CD}$ is a justifiable and promising treatment strategy.

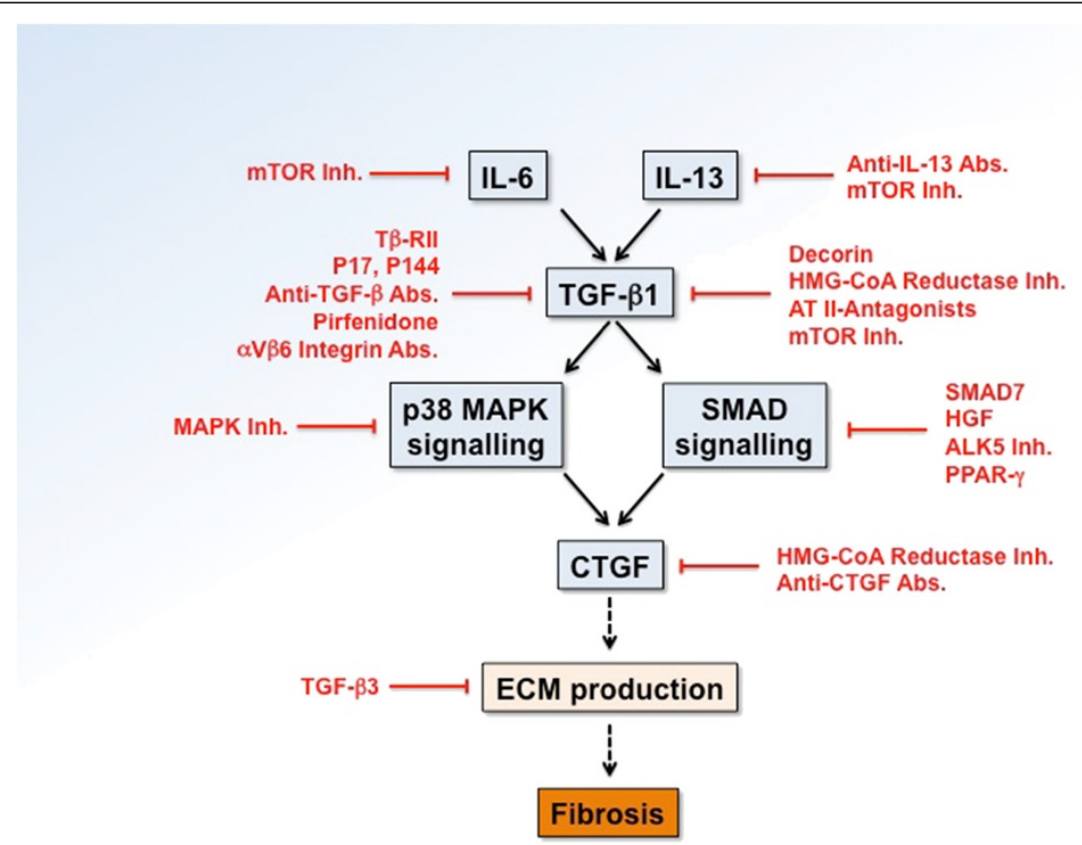

Figure 3 Compounds used as anti-fibrotic therapies in other organs and their mode of action. The blue boxes represent a major profibrotic pathway. Compounds are depicted in red, indicating their mechanism of action. Abs, antibodies; ALK, activin receptor-like kinase; AT, angiotensin; CTGF, connective tissue growth factor; ECM, extracellular matrix; HGF, hepatocyte growth factor; HMG-CoA, 3-hydroxy-3-methylglutaryl-coenzyme A; Inh, Inhibitor; IL, interleukin; MAPK, mitogen-activated protein kinase; MTOR, mammalian target of rapamycin; PPAR, peroxisome proliferator-activated receptor; SMAD, small mothers against decapentaplegic; TGF, transforming growth factor. 
Table 1 Completed clinical trials evaluating anti-fibrotic drugs in organs other than the gut

\begin{tabular}{|c|c|c|c|c|c|c|c|}
\hline Parameter & Author & $\begin{array}{l}\text { Study } \\
\text { organ }\end{array}$ & $\begin{array}{l}\text { Number of } \\
\text { patents }\end{array}$ & Type of trial & Study drug & Mode of action & Outcome measures \\
\hline \multirow[t]{4}{*}{ Growth factors } & Noble [95] & Lung & 779 & RCT, phase III & Pirfenidone & Inhibition of TGF- $\beta$ & Increased FVC in IPF \\
\hline & Trachtman [98] & Kidney & 16 & Open-label, phase I & Fresolimumab & $\begin{array}{l}\text { Antibody targeting all } \\
\text { isoforms of TGF- } \beta\end{array}$ & Safety, pharmacokinetics \\
\hline & Ferguson [111] & Skin & 223 & $\mathrm{RCT}$, phase $\mathrm{I} / \mathrm{I}$ & Avotermin & $\begin{array}{l}\text { Antibody targeting } \\
\text { TGF- } \beta 3\end{array}$ & $\begin{array}{l}\text { Acceleration and permanent improvement } \\
\text { in dermal scaring }\end{array}$ \\
\hline & Dillingh [114] & Lung & 29 & RCT, phase I & rhSAP & Substitution of SAP & $\begin{array}{l}\text { Reduction in SAP levels and circulating } \\
\text { fibrocytes in healthy control and } \\
\text { IPF patients }\end{array}$ \\
\hline \multirow[t]{3}{*}{ Oxidative stress } & Raghu [158] & Lung & 88 & RCT, phase II & Etanercept & Blockade of TNF & $\begin{array}{l}\text { Physiological and functional decrease in } \\
\text { disease progression in IPF }\end{array}$ \\
\hline & Corren [159] & Lung & 219 & RCT, phase II & Lebrikizumab & Antibody targeting IL-13 & $\begin{array}{l}\text { Improved lung function in asthmatic } \\
\text { patients }\end{array}$ \\
\hline & Horton [160] & Lung & 23 & RCT, phase III & Thalidomide & $\begin{array}{l}\text { Anti-angiogenic and } \\
\text { anti-inflammatory }\end{array}$ & $\begin{array}{l}\text { Improvement of cough and respiratory } \\
\text { quality of life in IPF }\end{array}$ \\
\hline \multirow[t]{2}{*}{$\begin{array}{l}\text { Intracellular enzymes } \\
\text { and receptors }\end{array}$} & Richeldi [162] & Lung & 432 & $\mathrm{RCT}$, phase II & BIBF 1120 & $\begin{array}{l}\text { Tyrosine kinase } \\
\text { inhibitor }\end{array}$ & $\begin{array}{l}\text { Tendency towards reduced decline of lung } \\
\text { function in IPF }\end{array}$ \\
\hline & Daniels [108] & Lung & 119 & $\mathrm{RCT}$, phase $\|/\| \|$ & Imatinib & $\begin{array}{l}\text { Tyrosine kinase } \\
\text { inhibitor }\end{array}$ & No effect on survival and lung function \\
\hline \multirow[t]{6}{*}{ ECM and other } & Couluris [140] & Lung & 20 & $\begin{array}{l}\text { Uncontrolled, interventional } \\
\text { study, phase II }\end{array}$ & Losartan & AT1 antagonist & Stabilization of lung function in IPF \\
\hline & el-Agroudy [142] & Kidney & 162 & RCT, phase II & Losartan & AT1 antagonist & $\begin{array}{l}\text { Decreased TGF- } \beta 1 \text { plasma levels and } \\
\text { proteinuria in renal interstitial fibrosis }\end{array}$ \\
\hline & Kuhn [182] & Skin & 10 & $\begin{array}{l}\text { Prospective, open-label, } \\
\text { phase II }\end{array}$ & Bosentan & $\begin{array}{l}\text { Endothelin receptor } \\
\text { antagonist }\end{array}$ & Reduced skin thickening in systemic sclerosis \\
\hline & Diez [141] & Heart & 34 & Uncontrolled, phase II & Losartan & AT1 antagonist & $\begin{array}{l}\text { Decreased myocardial collagen content and } \\
\text { left ventricular chamber stiffness in } \\
\text { hypertensive patients }\end{array}$ \\
\hline & De [143] & Liver & 39 & RCT, phase II & Losartan & AT1 antagonist & $\begin{array}{l}\text { Reduction of portal pressure in patients } \\
\text { with liver cirrhosis }\end{array}$ \\
\hline & King [183] & Lung & 616 & RCT & Bosentan & $\begin{array}{l}\text { Endothelin receptor } \\
\text { antagonist }\end{array}$ & $\begin{array}{l}\text { Improvement of FVC and diffusing capacity } \\
\text { in IPF }\end{array}$ \\
\hline
\end{tabular}


However, the simple transfer of these agents into CD treatment is premature and multiple obstacles have to be overcome to make use of the above described mediators and mechanisms.

First, the ideal anti-fibrotic drug should target something uniquely expressed in a specific fibrotic complication in a particular organ and should not display any systemic side effects. This is particularly true in case of concomitant injury elsewhere in the body. To date, however, no specific target for intestinal fibrosis or other fibrotic disease has been identified, which supports the hypothesis that mechanisms of fibrosis are shared between different organs.

Second, the optimal timing to commence anti-fibrotic treatment is of utmost importance to CD patients, however, is not defined yet. It is obvious that an early use of anti-fibrotics is expected to be associated with a better outcome in patients prone to this complication. Pre-existing fibrosis and concomitantly increased tissue stiffness can perpetuate fibrosis even in the absence of inflammation. Data from experimental fibrosis seems to confirm that there might be a critical point in evolution of fibrosis when the progress becomes irreversible [184]. Therefore, an early treatment with anti-fibrotics at the same time of antiinflammatory agents might be mandatory in human CD patients [185]. Unique to $\mathrm{CD}$ is a fistulizing disease process and this complication needs to be kept in mind when using drugs inhibiting tissue remodeling because this could theoretically promote fistulizing disease. However, timing may not be simply based on the disease duration, since up to $50 \%$ of $\mathrm{CD}$ patients present with stricturing or penetrating disease at the time of first diagnosis [186].
Third, a patient-tailored anti-fibrotic treatment approach necessitates the identification of biomarkers to enable individual risk stratifications for stricturing disease and to follow the individual evolution of fibrosis. As opposed to other organs, such as liver $[187,188]$ or lung [159], regrettably, no clinically useful biomarkers for stricturing $\mathrm{CD}$ as well as for assessment of therapeutic response are available yet. Promising approaches include serology [189,190] or imaging techniques [191-196], but the currently used tools only detect endpoints based on clinical findings of possible CD fibrosis and hence are not accurate.

Fourth, the best route of application for anti-fibrotic agents in stricturing $\mathrm{CD}$ has to be elucidated. In line with the beneficial effects of systemic administration of anti-fibrotics in other organs [24], intravenous or oral application may be appropriate. The CD intestine offers the advantage of potential local therapy as a large proportion of strictures is accessible via endoscopy. Intralesional injection or topical application of anti-fibrotics is a valid and practical therapeutic option, as shown by steroid [197] or infliximab application [198]. This approach may be associated with fewer side effects as compared to systemic administration.

Finally, a general limitation to evaluating potential anti-fibrotic agents is the long-lasting evolution of fibrotic complications in patients with $\mathrm{CD}$ requiring clinical trials of long duration and large patient populations, making them very expensive and impractical [24].

It is unclear and in the realm of speculation, which of the reviewed drugs has the highest potential for success as an anti-fibrotic treatment in CD. Combining drugs

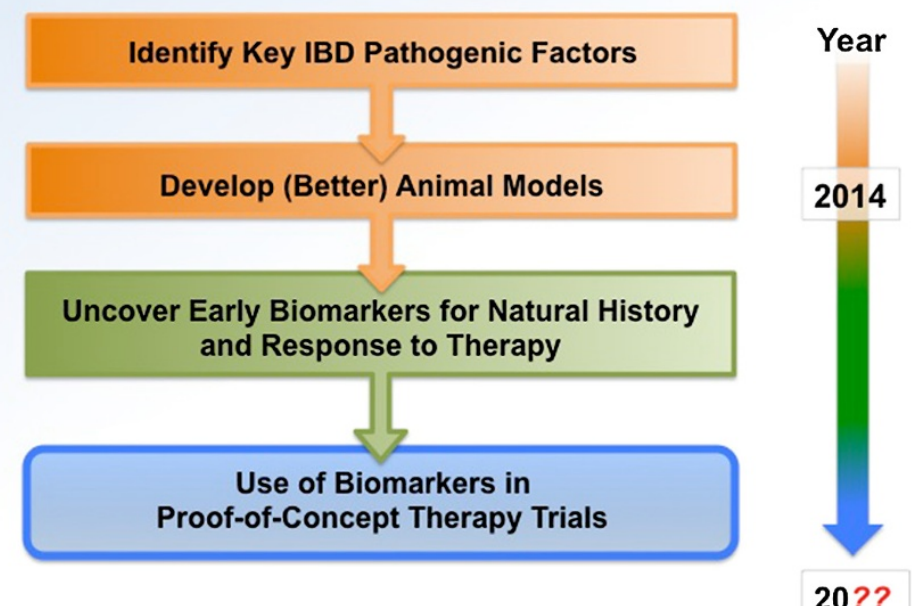

Figure 4 A suggested path to more efficient translation of new discoveries to Crohn's disease-associated fibrosis. Adapted from Friedman et al. [24]. IBD, inflammatory bowel disease. 
with a known safety profile and anti-fibrotic efficacy, such as HMG-CoA reductase inhibitors, mTOR inhibitors or inhibitors of the angiotensin system, could serve as a starting point. Given the effect of most substances on a reduction of TGF- $\beta 1$ proper precaution needs to be taken for carefully monitoring intestinal inflammation. Novel drug delivery systems, such as the Multi Matrix System $\left(\mathrm{MMX}^{\circ}\right)$, allowing oral administration of a compound with the substance being released in a defined area of the gastrointestinal tract (such as the terminal ileum) can circumvent systemic side effects, such as hypotension for angiotensin blockade.

To move forward with specific anti-fibrotic therapies in the future we need to focus on identifying mechanisms of fibrogenesis and to develop new and better animal models for this disease (Figure 4). What, however, is badly missing is the availability of biomarkers for natural history and response to therapy that are readily available and easy to measure. Only through utilization of these markers will the field be able to design clinical studies of reasonable length and sufficient patient number, reflected in affordable budgets that put our ability for testing antifibrotic therapies within reach.

\section{Conclusions}

Stricturing $C D$ is still an unresolved problem with strong implications for the patients and a high socioeconomic burden due to frequent hospitalizations and surgery [23]. Despite recent advances in the pathophysiological understanding of fibrosis and significant expansion of the anti-inflammatory armamentarium over the last few decades, the occurrence of intestinal strictures in CD patients did not significantly change. To date, effective therapeutic approaches for stricturing $\mathrm{CD}$ are limited to ED or surgical interventions. The data presented in this review highlight the pleiotropic antifibrotic actions that have been observed with the use of numerous agents in fibrotic complications of the skin, the lung and the kidney. Thus, it is justified to propose further evaluation of these drug candidates in clinical trials for the management of intestinal fibrosis. However, previous establishment of non-invasive biomarkers to assess the degree of fibrosis, to monitor fibrotic evolution and to predict therapeutic response, combined with the development of imaging techniques to quantify intestinal fibrosis, appear to be essential pre-requisites for individual risk stratification and proper design of clinical trials.

\section{Abbreviations}

6-MP: 6-Mercaptopurine; ACE: Angiotensin-converting enzyme; ALK: Activin receptor-like kinase; AT II: Angiotensin II; AZA: Azathioprine; bFGF: Basic fibroblast growth factor; c-Abl: c-Abelson; CD: Crohn's disease; CTGF: Connective tissue growth factor; DSS: Dextran sulfate sodium; ECM: Extracellular matrix; ED: Endoscopic dilation; EMT: Epithelial-mesenchymal transition; EndoMT: Endothelial-mesenchymal transition; HMG-CoA: 3-Hydroxy-3-methyl-glutaryl-coenzyme A; IBD: Inflammatory bowel disease; IGF: Insulin-like growth factor; IL: Interleukin; IPF: Idiopathic pulmonary fibrosis; MAPK: Mitogen-activated protein kinase; MMP: Matrix metalloproteinase; mTOR: Mammalian target of rapamycin; NF-kB: Nuclear factor kappa-light-chainenhancer of activated B cells; NIH: National Institutes of Health; NLM: National Library of Medicine; PDGF: Platelet-derived growth factor; PG-PS: Peptidoglycanpolysaccharide; PPAR: Peroxisome proliferator-activated receptor; RAS: Reninangiotensin system; ROCK: Rho-associated protein kinase; SAP: Serum amyloid P component; TGF: Transforming growth factor; THBS: Thrombospondin; TIMP: Tissue inhibitor of metalloproteinase; TLR: Toll-like receptor; TNBS: 2,4,6-Trinitrobenzene sulfonic acid; TNF: Tumor necrosis factor; VEGF: Vascular endothelial growth factor.

\section{Competing interests}

The authors declare that they have no competing interests.

\section{Authors' contributions}

DB and FR developed the review concept, performed the literature review and wrote the manuscript. Both authors read and approved the final version of the manuscript.

\section{Acknowledgements}

DB was supported by a research fellowship from the Faculty of Medicine, University of Münster, Münster, Germany. FR is funded by the NIH (grant: 1T32DK083251-01A1). The authors would like to thank Dr Claudio Fiocchi and Dr Bo Shen, Department of Gastroenterology, Hepatology and Nutrition, Cleveland Clinic Foundation, Cleveland, OH, USA, for helpful comments.

\section{Author details}

${ }^{1}$ Department of Medicine B, University Hospital of Münster, Münster, Germany. ${ }^{2}$ Department of Gastroenterology and Hepatology, Digestive Disease Institute, Cleveland Clinic Foundation, Cleveland, OH, USA. ${ }^{3}$ Department of Pathobiology, Lerner Research Institute, NC22, Cleveland Clinic Foundation, 9500 Euclid Avenue, Cleveland, OH 44195, USA.

Received: 3 January 2014 Accepted: 6 March 2014

Published: 29 March 2014

\section{References}

1. Baumgart DC, Sandborn WJ: Crohn's disease. Lancet 2012, 380:1590-1605.

2. Cheifetz AS: Management of active Crohn disease. JAMA 2013 309:2150-2158.

3. Cosnes J, Gower-Rousseau C, Seksik P, Cortot A: Epidemiology and natural history of inflammatory bowel diseases. Gastroenterology 2011, 140:1785-1794.

4. Lenze F, Wessling J, Bremer J, Ullerich H, Spieker T, Weckesser M, Gonschorrek S, Kannengiesser K, Rijcken E, Heidemann J, Luegering A, Schober O, Domschke W, Kucharzik T, Maaser C: Detection and differentiation of inflammatory versus fibromatous Crohn's disease strictures: prospective comparison of 18 F-FDG-PET/CT, MR-enteroclysis, and transabdominal ultrasound versus endoscopic/histologic evaluation. Inflamm Bowel Dis 2012, 18:2252-2260.

5. Schoepfer AM, Safroneeva E, Vavricka SR, Peyrin-Biroulet L, Mottet C: Treatment of fibrostenotic and fistulizing Crohn's disease. Digestion 2012, 86(Suppl 1):23-27.

6. Hanauer SB, Feagan BG, Lichtenstein GR, Mayer LF, Schreiber S, Colombel JF, Rachmilewitz D, Wolf DC, Olson A, Bao W, Rutgeerts P, ACCENT I Study Group: Maintenance infliximab for Crohn's disease: the ACCENT I randomised trial. Lancet 2002, 359:1541-1549.

7. Sandborn WJ, Hanauer SB, Rutgeerts P, Fedorak RN, Lukas M, MacIntosh DG, Panaccione R, Wolf D, Kent JD, Bittle B, Li J, Pollack PF: Adalimumab for maintenance treatment of Crohn's disease: results of the CLASSIC II trial. Gut 2007, 56:1232-1239.

8. Colombel JF, Sandborn WJ, Rutgeerts P, Enns R, Hanauer SB, Panaccione R, Schreiber S, Byczkowski D, Li J, Kent JD, Pollack PF: Adalimumab for maintenance of clinical response and remission in patients with Crohn's disease: the CHARM trial. Gastroenterology 2007, 132:52-65.

9. Cosnes J, Nion-Larmurier I, Beaugerie L, Afchain P, Tiret E, Gendre JP: Impact of the increasing use of immunosuppressants in Crohn's disease on the need for intestinal surgery. Gut 2005, 54:237-241.

10. Rieder F, Zimmermann EM, Remzi FH, Sandborn WJ: Crohn's disease complicated by strictures: a systematic review. Gut 2013, 62:1072-1084. 
11. Rieder F, Fiocchi C: Intestinal fibrosis in inflammatory bowel disease: progress in basic and clinical science. Curr Opin Gastroenterol 2008, 24:462-468.

12. Hassan C, Zullo A, De Francesco V, lerardi E, Giustini M, Pitidis A, Taggi F, Winn S, Morini S: Systematic review: endoscopic dilatation in Crohn's disease. Aliment Pharmacol Ther 2007, 26:1457-1464.

13. Thienpont C, D'Hoore A, Vermeire S, Demedts I, Bisschops R, Coremans G, Rutgeerts $P$, Van Assche G: Long-term outcome of endoscopic dilatation in patients with Crohn's disease is not affected by disease activity or medical therapy. Gut 2010, 59:320-324.

14. Singh W, Draganov P, Valentine J: Efficacy and safety of endoscopic balloon dilation of symptomatic upper and lower gastrointestinal Crohn's disease strictures. J Clin Gastroenterol 2005, 39:284-290.

15. Hoffmann JC, Heller F, Faiss S, von Lampe B, Kroesen AJ, Wahnschaffe U, Schulzke JD, Zeitz M, Bojarski C: Through the endoscope balloon dilation of ileocolonic strictures: prognostic factors, complications, and effectiveness. Int J Colorectal Dis 2008, 23:689-696.

16. Froehlich F, Juillerat $P$, Pittet $V$, Felley C, Mottet C, Vader JP, Michetti $P$, Gonvers JJ: Maintenance of surgically induced remission of Crohn's disease. Digestion 2007, 76:130-135.

17. Despott EJ, Gupta A, Burling D, Tripoli E, Konieczko K, Hart A, Fraser C: Effective dilation of small-bowel strictures by double-balloon enteroscopy in patients with symptomatic Crohn's disease (with video). Gastrointest Endosc 2009, 70:1030-1036.

18. Gustavsson A, Magnuson A, Blomberg B, Andersson M, Halfvarson J, Tysk C: Endoscopic dilation is an efficacious and safe treatment of intestinal strictures in Crohn's disease. Aliment Pharmacol Ther 2012, 36:151-158.

19. Wibmer AG, Kroesen AJ, Grone J, Buhr HJ, Ritz JP: Comparison of strictureplasty and endoscopic balloon dilatation for stricturing Crohn's disease-review of the literature. Int J Colorectal Dis 2010, 25:1149-1157.

20. Baba S, Nakai K: Strictureplasty for Crohn's disease in Japan. J Gastroenterol 1995, 30(Suppl 8):135-138.

21. Ambe R, Campbell L, Cagir B: A comprehensive review of strictureplasty techniques in Crohn's disease: types, indications, comparisons, and safety. J Gastrointest Surg 2012, 16:209-217.

22. Rutgeerts P, Geboes K, Vantrappen G, Beyls J, Kerremans R, Hiele M: Predictability of the postoperative course of Crohn's disease. Gastroenterology 1990, 99:956-963.

23. Bodger K, Kikuchi T, Hughes D: Cost-effectiveness of biological therapy for Crohn's disease: Markov cohort analyses incorporating United Kingdom patient-level cost data. Aliment Pharmacol Ther 2009, 30:265-274.

24. Friedman SL, Sheppard D, Duffield JS, Violette S: Therapy for fibrotic diseases: nearing the starting line. Sci Transl Med 2013, 5:167sr1.

25. Fichtner-Feigl S, Young CA, Kitani A, Geissler EK, Schlitt HJ, Strober W: IL-13 signaling via IL-13R alpha2 induces major downstream fibrogenic factors mediating fibrosis in chronic TNBS colitis. Gastroenterology 2008, 135:2003-2013.

26. Zhu MY, Lu YM, Ou YX, Zhang HZ, Chen WX: Dynamic progress of 2,4,6-trinitrobenzene sulfonic acid induced chronic colitis and fibrosis in rat model. J Dig Dis 2012, 13:421-429.

27. Vallance BA, Gunawan MI, Hewlett B, Bercik P, Van Kampen C, Galeazzi F, Sime PJ, Gauldie J, Collins SM: TGF-beta1 gene transfer to the mouse colon leads to intestinal fibrosis. Am J Physiol Gastrointest Liver Physiol 2005, 289:G116-G128.

28. Mahavadi S, Flynn RS, Grider JR, Qiao LY, Murthy KS, Hazelgrove KB, Kuemmerle JF: Amelioration of excess collagen lalphal, fibrosis, and smooth muscle growth in TNBS-induced colitis in IGF-I(+/-) mice. Inflamm Bowel Dis 2011, 17:711-719.

29. Kumagai S, Ohtani H, Nagai T, Funa K, Hiwatashi NO, Shimosegawa, Nagura H: Platelet-derived growth factor and its receptors are expressed in areas of both active inflammation and active fibrosis in inflammatory bowel disease. Tohoku J Exp Med 2001, 195:21-33.

30. Lawrance IC, Maxwell L, Doe W: Altered response of intestinal mucosal fibroblasts to profibrogenic cytokines in inflammatory bowel disease. Inflamm Bowel Dis 2001, 7:226-236.

31. Wynn TA, Ramalingam TR: Mechanisms of fibrosis: therapeutic translation for fibrotic disease. Nat Med 2012, 18:1028-1040.

32. Rieder F, Fiocchi C: Intestinal fibrosis in IBD - a dynamic, multifactorial process. Nat Rev Gastroenterol Hepatol 2009, 6:228-235.

33. Fichtner-Feigl S, Strober W, Kawakami K, Puri RK, Kitani A: IL-13 signaling through the IL-13alpha2 receptor is involved in induction of TGF-beta1 production and fibrosis. Nat Med 2006, 12:99-106.
34. Akiho $H$, Lovato $P$, Deng $Y$, Ceponis PJ, Blennerhassett $P$, Collins SM: Interleukin-4- and -13-induced hypercontractility of human intestinal muscle cells-implication for motility changes in Crohn's disease. Am J Physiol Gastrointest Liver Physiol 2005, 288:G609-G615.

35. Bailey JR, Bland PW, Tarlton JF, Peters I, Moorghen M, Sylvester PA, Probert CS, Whiting CV: IL-13 promotes collagen accumulation in Crohn's disease fibrosis by down-regulation of fibroblast MMP synthesis: a role for innate lymphoid cells? PLoS One 2012, 7:e52332.

36. Biancheri P, Di Sabatino A, Ammoscato F, Facciotti F, Caprioli F, Curciarello R, Hoque SS, Ghanbari A, Joe-Njoku I, Giuffrida P, Rovedatti L, Geginat J, Corazza GR, Macdonald TT: Absence of a role for interleukin-13 in inflammatory bowel disease. Eur J Immunol 2014, 44:370-385.

37. Valente AJ, Yoshida T, Gardner JD, Somanna N, Delafontaine P, Chandrasekar B: Interleukin-17A stimulates cardiac fibroblast proliferation and migration via negative regulation of the dual-specificity phosphatase MKP-1/DUSP-1. Cell Signal 2012, 24:560-568

38. Meng F, Wang K, Aoyama T, Grivennikov SI, Paik Y, Scholten D, Cong M, Iwaisako K, Liu X, Zhang M, Osterreicher CH, Stickel F, Ley K, Brenner DA, Kisseleva T: Interleukin-17 signaling in inflammatory, Kupffer cells, and hepatic stellate cells exacerbates liver fibrosis in mice. Gastroenterology 2012, 143:765-776.

39. Okamoto Y, Hasegawa M, Matsushita T, Hamaguchi Y, Huu DL, Iwakura Y, Fujimoto $M$, Takehara $K$ : Potential roles of interleukin-17A in the development of skin fibrosis in mice. Arthritis Rheum 2012, 64:3726-3735.

40. Mi S, Li Z, Yang HZ, Liu H, Wang JP, Ma YG, Wang XX, Liu HZ, Sun W, Hu ZW Blocking IL-17A promotes the resolution of pulmonary inflammation and fibrosis via TGF-beta1-dependent and -independent mechanisms. J Immunol 2011, 187:3003-3014.

41. Gregory LG, Jones CP, Walker SA, Sawant D, Gowers KH, Campbell GA, McKenzie AN, Lloyd CM: IL-25 drives remodelling in allergic airways disease induced by house dust mite. Thorax 2013, 68:82-90

42. Biancheri P, Pender SL, Ammoscato F, Giuffrida P, Sampietro G, Ardizzone S, Ghanbari A, Curciarello R, Pasini A, Monteleone G, Corazza GR, Macdonald $\Pi$, Di Sabatino A: The role of interleukin 17 in Crohn's disease-associated intestinal fibrosis. Fibrogenesis Tissue Repair 2013, 6:13.

43. Hueber W, Sands BE, Lewitzky S, Vandemeulebroecke M, Reinisch W, Higgins PD, Wehkamp J, Feagan BG, Yao MD, Karczewski M, Karczewski J, Pezous N, Bek S, Bruin G, Mellgard B, Berger C, Londei M, Bertolino AP, Tougas G, Travis SP, Secukinumab in Crohn's Disease Study Group: Secukinumab, a human anti-IL-17A monoclonal antibody, for moderate to severe Crohn's disease: unexpected results of a randomised, double-blind placebo-controlled trial. Gut 2012, 61:1693-1700.

44. Hawinkels $L$, Ten Dijke P: Exploring anti-TGF-beta therapies in cancer and fibrosis. Growth Factors 2011, 29:140-152.

45. Munger JS, Harpel JG, Gleizes PE, Mazzieri R, Nunes I, Rifkin DB: Latent transforming growth factor-beta: structural features and mechanisms of activation. Kidney Int 1997, 51:1376-1382

46. Latella G, Sferra R, Speca S, Vetuschi A, Gaudio E: Can we prevent, reduce or reverse intestinal fibrosis in IBD? Eur Rev Med Pharmacol Sci 2013, 17:1283-1304

47. Monteleone G, Pallone F, MacDonald T: Smad7 in TGF-beta-mediated negative regulation of gut inflammation. Trends Immuno/ 2004, 25:513-517

48. McKaig BC, McWilliams D, Watson SA, Mahida YR: Expression and regulation of tissue inhibitor of metalloproteinase-1 and matrix metalloproteinases by intestinal myofibroblasts in inflammatory bowel disease. Am J Pathol 2003, 162:1355-1360

49. Medina C, Santos-Martinez MJ, Santana A, Paz-Cabrera MC, Johnston MJ, Mourelle M, Salas A, Guarner F: Transforming growth factor-beta type receptor (ALK5) and Smad proteins mediate TIMP-1 and collagen synthesis in experimental intestinal fibrosis. J Pathol 2011, 224:461-472.

50. Rieder F, Georgieva M, Schirbel A, Artinger M, Zugner A, Blank M, Brenmoehl J, Scholmerich J, Rogler G: Prostaglandin E2 inhibits migration of colonic lamina propria fibroblasts. Inflamm Bowel Dis 2010, 16:1505-1513.

51. Brittan M, Chance V, Elia G, Poulsom R, Alison MR, MacDonald TT, Wright NA: A regenerative role for bone marrow following experimental colitis: contribution to neovasculogenesis and myofibroblasts. Gastroenterology 1984-1995, 2005:128.

52. Kalluri R: EMT: when epithelial cells decide to become mesenchymal-like cells. J Clin Invest 2009, 119:1417-1419. 
53. Otte JM, Rosenberg IM, Podolsky DK: Intestinal myofibroblasts in innate immune responses of the intestine. Gastroenterology 1866-1878, 2003:124

54. Rieder F, Kessler S, Sans M, Fiocchi C: Animal models of intestinal fibrosis: new tools for the understanding of pathogenesis and therapy of human disease. Am J Physiol Gastrointest Liver Physiol 2012, 303:G786-G801.

55. Jostins L, Ripke S, Weersma RK, Duerr RH, McGovern DP, Hui KY, Lee JC, Schumm LP, Sharma Y, Anderson CA, Essers J, Mitrovic M, Ning K, Cleynen I, Theatre E, Spain SL, Raychaudhuri S, Goyette P, Wei Z, Abraham C, Achkar JP, Ahmad T, Amininejad L, Ananthakrishnan AN, Andersen V, Andrews JM, Baidoo L, Balschun T, Bampton PA, Bitton A, et al: Host-microbe interactions have shaped the genetic architecture of inflammatory bowel disease. Nature 2012, 491:119-124.

56. Dubinsky MC, Lin YC, Dutridge D, Picornell Y, Landers CJ, Farrior S, Wrobel I, Quiros A, Vasiliauskas EA, Grill B, Israel D, Bahar R, Christie D, Wahbeh G, Silber G, Dallazadeh S, Shah P, Thomas D, Kelts D, Hershberg RM, Elson CO, Targan SR, Taylor KD, Rotter JI, Yang H, Western Regional Pediatric IBD Research Alliance: Serum immune responses predict rapid disease progression among children with Crohn's disease: immune responses predict disease progression. Am J Gastroenterol 2006, 101:360-367.

57. Rieder F, Schleder S, Wolf A, Dirmeier A, Strauch U, Obermeier F, Lopez R, Spector L, Fire E, Yarden J, Rogler G, Dotan N, Klebl F: Serum anti-glycan antibodies predict complicated Crohn's disease behavior: a cohort study. Inflamm Bowel Dis 2010, 16:1367-1375.

58. Rieder F, Schleder S, Wolf A, Dirmeier A, Strauch U, Obermeier F, Lopez R, Spector L, Fire E, Yarden J, Rogler G, Dotan N, Klebl F: Association of the novel serologic anti-glycan antibodies anti-laminarin and anti-chitin with complicated Crohn's disease behavior. Inflamm Bowel Dis 2010, $16: 263-274$

59. Geboes KP, Cabooter L, Geboes K: Contribution of morphology for the comprehension of mechanisms of fibrosis in inflammatory enterocolitis. Acta Gastroenterol Belg 2000, 63:371-376.

60. Graham MF, Diegelmann RF, Elson CO, Lindblad WJ, Gotschalk N, Gay S, Gay R: Collagen content and types in the intestinal strictures of Crohn's disease. Gastroenterology 1988, 94:257-265.

61. Borley NR, Mortensen NJ, Kettlewell MG, George BD, Jewell DP, Warren BF: Connective tissue changes in ileal Crohn's disease: relationship to disease phenotype and ulcer-associated cell lineage. Dis Colon Rectum 2001, 44:388-396.

62. Geboes K, El-Zine MY, Dalle I, El-Haddad S, Rutgeerts P, Van Eyken P: Tenascin and strictures in inflammatory bowel disease: an immunohistochemical study. Int J Surg Pathol 2001, 9:281-286.

63. Gelbmann CM, Mestermann S, Gross V, Kollinger M, Scholmerich J, Falk W: Strictures in Crohn's disease are characterised by an accumulation of mast cells colocalised with laminin but not with fibronectin or vitronectin. Gut 1999, 45:210-217.

64. Wells RG: The role of matrix stiffness in regulating cell behavior. Hepatology 2008, 47:1394-1400.

65. Ura H, Obara T, Yokota K, Shibata Y, Okamura K, Namiki M: Effects of transforming growth factor-beta released from gastric carcinoma cells on the contraction of collagen-matrix gels containing fibroblasts. Cancer Res 1991, 51:3550-3554.

66. Hinz B: Tissue stiffness, latent TGF-beta1 activation, and mechanical signal transduction: implications for the pathogenesis and treatment of fibrosis. Curr Rheumatol Rep 2009, 11:120-126.

67. Oikarinen Al, Vuorio El, Zaragoza EJ, Palotie A, Chu ML, Uitto J: Modulation of collagen metabolism by glucocorticoids. Receptor-mediated effects of dexamethasone on collagen biosynthesis in chick embryo fibroblasts and chondrocytes. Biochem Pharmacol 1988, 37:1451-1462.

68. Ketchum LD, Smith J, Robinson DW, Masters FW: The treatment of hypertrophic scar, keloid and scar contracture by triamcinolone acetonide. Plast Reconstr Surg 1966, 38:209-218.

69. Vaglio A, Palmisano A, Alberici F, Maggiore U, Ferretti S, Cobelli R, Ferrozzi F, Corradi D, Salvarani C, Buzio C: Prednisone versus tamoxifen in patients with idiopathic retroperitoneal fibrosis: an open-label randomised controlled trial. Lancet 2011, 378:338-346

70. Badea I, Taylor M, Rosenberg A, Foldvari M: Pathogenesis and therapeutic approaches for improved topical treatment in localized scleroderma and systemic sclerosis. Rheumatology (Oxford) 2009, 48:213-221.

71. Peikert T, Daniels CE, Beebe TJ, Meyer KC, Ryu JH, Interstitial Lung Diseases Network of the American College of Chest Physicians: Assessment of current practice in the diagnosis and therapy of idiopathic pulmonary fibrosis. Respir Med 2008, 102:1342-1348.

72. Graham MF, Willey A, Adams J, Diegelmann RF: Corticosteroids increase procollagen gene expression, synthesis, and secretion by human intestinal smooth muscle cells. Gastroenterology 1995, 109:1454-1461.

73. Kochhar R, Poornachandra KS: Intralesional steroid injection therapy in the management of resistant gastrointestinal strictures. World J Gastrointest Endosc 2010, 2:61-68.

74. Warnatz K, Keskin AG, Uhl M, Scholz C, Katzenwadel A, Vaith P, Peter HH, Walker UA: Immunosuppressive treatment of chronic periaortitis: a retrospective study of 20 patients with chronic periaortitis and a review of the literature. Ann Rheum Dis 2005, 64:828-833.

75. Rogliani P, Mura M, Assunta Porretta M, Saltini C: New perspectives in the treatment of idiopathic pulmonary fibrosis. Ther Adv Respir Dis 2008, 2:75-93.

76. Dheda K, Lalloo UG, Cassim B, Mody GM: Experience with azathioprine in systemic sclerosis associated with interstitial lung disease. Clin Rheumatol 2004, 23:306-309.

77. Peyrin-Biroulet L, Deltenre P, Ardizzone S, D'Haens G, Hanauer SB, Herfarth $\mathrm{H}$, Lemann M, Colombel JF: Azathioprine and 6-mercaptopurine for the prevention of postoperative recurrence in Crohn's disease: a metaanalysis. Am J Gastroenterol 2089-2096, 2009:104.

78. Spinelli A, Correale C, Szabo H, Montorsi M: Intestinal fibrosis in Crohn's disease: medical treatment or surgery? Curr Drug Targets 2010, 11:242-248.

79. Hanauer SB, Sandborn WJ, Rutgeerts P, Fedorak RN, Lukas M, MacIntosh D, Panaccione $R$, Wolf D, Pollack P: Human anti-tumor necrosis factor monoclonal antibody (adalimumab) in Crohn's disease: the CLASSIC-I trial. Gastroenterology 2006, 130:323-333. quiz 591.

80. Colombel JF, Sandborn WJ, Reinisch W, Mantzaris GJ, Kornbluth A, Rachmilewitz D, Lichtiger S, D'Haens G, Diamond RH, Broussard DL, Tang KL, van der Woude CJ, Rutgeerts P, SONIC Study Group: Infliximab, azathioprine, or combination therapy for Crohn's disease. N Engl J Med 2010, 362:1383-1395.

81. Sandborn WJ, Feagan BG, Marano C, Zhang H, Strauss R, Johanns J, Adedokun OJ, Guzzo C, Colombel JF, Reinisch W, Gibson PR, Collins J, Jarnerot G, Hibi T, Rutgeerts P, PURSUIT-SC Study Group: Subcutaneous golimumab induces clinical response and remission in patients with moderate-to-severe ulcerative colitis. Gastroenterology 2014, 146:85-95.

82. Sandborn WJ, Feagan BG, Stoinov S, Honiball PJ, Rutgeerts P, Mason D, Bloomfield R, Schreiber S, PRECISE 1 Study Investigators: Certolizumab pegol for the treatment of Crohn's disease. N Engl J Med 2007, 357:228-238.

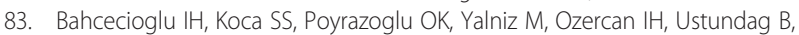
Sahin K, Dagli AF, Isik A: Hepatoprotective effect of infliximab, an anti-TNF-alpha agent, on carbon tetrachloride-induced hepatic fibrosis. Inflammation 2008, 31:215-221.

84. Antoniou KM, Mamoulaki M, Malagari K, Kritikos HD, Bouros D, Siafakas NM Boumpas DT: Infliximab therapy in pulmonary fibrosis associated with collagen vascular disease. Clin Exp Rheumatol 2007, 25:23-28.

85. Bargagli E, Galeazzi M, Bellisai F, Volterrani L, Rottoli P: Infliximab treatment in a patient with systemic sclerosis associated with lung fibrosis and pulmonary hypertension. Respiration 2008, 75:346-349.

86. Theiss AL, Simmons JG, Jobin C, Lund PK: Tumor necrosis factor (TNF) alpha increases collagen accumulation and proliferation in intestinal myofibroblasts via TNF receptor 2. J Biol Chem 2005, 280:36099-36109.

87. Di Sabatino A, Pender SL, Jackson CL, Prothero JD, Gordon JN, Picariello L, Rovedatti L, Docena G, Monteleone G, Rampton DS, Tonelli F, Corazza GR, MacDonald TT: Functional modulation of Crohn's disease myofibroblasts by anti-tumor necrosis factor antibodies. Gastroenterology 2007, 133:137-149.

88. Lichtenstein GR, Olson A, Travers S, Diamond RH, Chen DM, Pritchard ML, Feagan BG, Cohen RD, Salzberg BA, Hanauer SB, Sandborn WJ: Factors associated with the development of intestinal strictures or obstructions in patients with Crohn's disease. Am J Gastroenterol 2006, 101:1030-1038.

89. Pelletier AL, Kalisazan B, Wienckiewicz J, Bouarioua N, Soule JC: Infliximab treatment for symptomatic Crohn's disease strictures. Aliment Pharmacol Ther 2009, 29:279-285.

90. Schnitzler F, Fidder H, Ferrante M, Noman M, Arijs I, Van Assche G, Hoffman I, Van Steen K, Vermeire S, Rutgeerts P: Long-term outcome of treatment with infliximab in 614 patients with Crohn's disease: results from a single-centre cohort. Gut 2009, 58:492-500.

91. Yamada M, Kuwano K, Maeyama T, Yoshimi M, Hamada N, Fukumoto J, Egashira K, Hiasa K, Takayama K, Nakanishi Y: Gene transfer of soluble transforming growth factor type II receptor by in vivo electroporation attenuates lung injury and fibrosis. J Clin Pathol 2007, 60:916-920. 
92. Arribillaga L, Dotor J, Basagoiti M, Riezu-Boj Jl, Borras-Cuesta F, Lasarte JJ, Sarobe P, Cornet ME, Feijoo E: Therapeutic effect of a peptide inhibitor of TGF-beta on pulmonary fibrosis. Cytokine 2011, 53:327-333.

93. Ezquerro IJ, Lasarte JJ, Dotor J, Castilla-Cortazar I, Bustos M, Penuelas I, Blanco G, Rodriguez C, Lechuga Mdel C, Greenwel P, Rojkind M, Prieto J, Borras-Cuesta F: A synthetic peptide from transforming growth factor beta type III receptor inhibits liver fibrogenesis in rats with carbon tetrachloride liver injury. Cytokine 2003, 22:12-20.

94. Azuma A: Pirfenidone treatment of idiopathic pulmonary fibrosis. Ther Adv Respir Dis 2012, 6:107-114.

95. Noble PW, Albera C, Bradford WZ, Costabel U, Glassberg MK, Kardatzke D, King TE Jr, Lancaster L, Sahn SA, Szwarcberg J, Valeyre D, du Bois RM, CAPACITY Study Group: Pirfenidone in patients with idiopathic pulmonary fibrosis (CAPACITY): two randomised trials. Lancet 2011, 377:1760-1769.

96. Akhurst RJ, Hata A: Targeting the TGFbeta signalling pathway in disease. Nat Rev Drug Discov 2012, 11:790-811.

97. Beyer C, Distler O, Distler JH: Innovative antifibrotic therapies in systemic sclerosis. Curr Opin Rheumatol 2012, 24:274-280.

98. Trachtman H, Fervenza FC, Gipson DS, Heering P, Jayne DR, Peters H, Rota S, Remuzzi G, Rump LC, Sellin LK, Heaton JP, Streisand JB, Hard ML, Ledbetter SR, Vincenti F: A phase 1, single-dose study of fresolimumab, an anti-TGF-beta antibody, in treatment-resistant primary focal segmental glomerulosclerosis. Kidney Int 2011, 79:1236-1243.

99. Crunkhorn S: Deal watch: Biogen acquires Stromedix to pursue novel fibrosis therapy. Nat Rev Drug Discov 2012, 11:260.

100. Alan C, Kocoglu H, Altintas R, Alici B, Resit Ersay A: Protective effect of decorin on acute ischaemia-reperfusion injury in the rat kidney. Arch Med Sci 2011, 7:211-216.

101. Terada Y, Hanada S, Nakao A, Kuwahara M, Sasaki S, Marumo F: Gene transfer of Smad7 using electroporation of adenovirus prevents renal fibrosis in post-obstructed kidney. Kidney Int 2002, 61:S94-S98.

102. Lu A, Miao M, Schoeb TR, Agarwal A, Murphy-Ullrich JE: Blockade of TSP1-dependent TGF-beta activity reduces renal injury and proteinuria in a murine model of diabetic nephropathy. Am J Pathol 2011, 178:2573-2586.

103. Liu Y: Hepatocyte growth factor in kidney fibrosis: therapeutic potential and mechanisms of action. Am J Physiol Renal Physiol 2004, 287:F7-F16.

104. Liu Y: Renal fibrosis: new insights into the pathogenesis and therapeutics. Kidney Int 2006, 69:213-217.

105. Szabo H, Fiorino G, Spinelli A, Rovida S, Repici A, Malesci AC, Danese S: Review article: anti-fibrotic agents for the treatment of Crohn's disease - lessons learnt from other diseases. Aliment Pharmacol Ther 2010, 31:189-201.

106. Daniels CE, Wilkes MC, Edens M, Kottom TJ, Murphy SJ, Limper AH, Leof EB: Imatinib mesylate inhibits the profibrogenic activity of TGF-beta and prevents bleomycin-mediated lung fibrosis. J Clin Invest 2004, 114:1308-1316.

107. Gordon J, Spiera R: Tyrosine kinase inhibitors in the treatment of systemic sclerosis: the difficulty in interpreting proof-of-concept studies. Int J Rheumatol 2011, 2011:842181.

108. Daniels CE, Lasky JA, Limper AH, Mieras K, Gabor E, Schroeder DR, Imatinib-IPF Study Investigators: Imatinib treatment for idiopathic pulmonary fibrosis: Randomized placebo-controlled trial results. Am J Respir Crit Care Med 2010, 181:604-610.

109. Kantarjian H, Jabbour E, Grimley J, Kirkpatrick P: Dasatinib. Nat Rev Drug Discov 2006, 5:717-718.

110. Gordon J, Spiera R: Imatinib and the treatment of fibrosis: recent trials and tribulations. Curr Rheumatol Rep 2011, 13:51-58.

111. Ferguson MW, Duncan J, Bond J, Bush J, Durani P, So K, Taylor L, Chantrey J, Mason T, James G, Laverty H, Occleston NL, Sattar A, Ludlow A, O'Kane S: Prophylactic administration of avotermin for improvement of skin scarring: three double-blind, placebo-controlled, phase I/II studies. Lancet 2009, 373:1264-1274.

112. Haudek SB, Xia Y, Huebener P, Lee JM, Carlson S, Crawford JR, Pilling D, Gomer RH, Trial J, Frangogiannis NG, Entman ML: Bone marrow-derived fibroblast precursors mediate ischemic cardiomyopathy in mice. Proc Natl Acad Sci U S A 2006, 103:18284-18289.

113. Pilling D, Roife D, Wang M, Ronkainen SD, Crawford JR, Travis EL, Gomer RH: Reduction of bleomycin-induced pulmonary fibrosis by serum amyloid $\mathrm{P}$. $\mathrm{J}$ Immunol 2007, 179:4035-4044.

114. Dillingh MR, van den Blink B, Moerland M, van Dongen MG, Levi M, Kleinjan A, Wijsenbeek MS, Lupher ML Jr, Harper DM, Getsy JA, Hoogsteden HC, Burggraaf J: Recombinant human serum amyloid $\mathrm{P}$ in healthy volunteers and patients with pulmonary fibrosis. Pulm Pharmacol Ther 2013, 26:672-676.

115. Latella G, Sferra R, Vetuschi A, Zanninelli G, D'Angelo A, Catitti V, Caprilli R, Gaudio E: Prevention of colonic fibrosis by Boswellia and Scutellaria extracts in rats with colitis induced by 2,4,5-trinitrobenzene sulphonic acid. Eur J Clin Invest 2008, 38:410-420.

116. Di Sabatino A, Jackson CL, Pickard KM, Buckley M, Rovedatti L, Leakey NA, Picariello L, Cazzola P, Monteleone G, Tonelli F, Corazza GR, MacDonald TT, Pender SL: Transforming growth factor beta signalling and matrix metalloproteinases in the mucosa overlying Crohn's disease strictures. Gut 2009, 58:777-789.

117. Bierie B, Moses HL: Tumour microenvironment: TGFbeta: the molecular Jekyll and Hyde of cancer. Nat Rev Cancer 2006, 6:506-520.

118. Diebold RJ, Eis MJ, Yin M, Ormsby I, Boivin GP, Darrow BJ, Saffitz JE, Doetschman T: Early-onset multifocal inflammation in the transforming growth factor beta 1-null mouse is lymphocyte mediated. Proc Natl Acad Sci U S A 1995, 92:12215-12219.

119. Kulkarni AB, Ward JM, Yaswen L, Mackall CL, Bauer SR, Huh CG, Gress RE, Karlsson S: Transforming growth factor-beta 1 null mice. An animal model for inflammatory disorders. Am J Pathol 1995, 146:264-275.

120. Boivin GP, Ormsby I, Jones-Carson J, OToole BA, Doetschman T: Germ-free and barrier-raised TGF beta 1-deficient mice have similar inflammatory lesions. Transgenic Res 1997, 6:197-202.

121. Gorelik L, Flavell RA: Abrogation of TGFbeta signaling in T cells leads to spontaneous T cell differentiation and autoimmune disease. Immunity 2000, 12:171-181.

122. Nomura M, Li E: Smad2 role in mesoderm formation, left-right patterning and craniofacial development. Nature 1998, 393:786-790.

123. Yang X, Li C, Xu X, Deng C: The tumor suppressor SMAD4/DPC4 is essential for epiblast proliferation and mesoderm induction in mice. Proc Natl Acad SCi USA 1998, 95:3667-3672.

124. Denton CP, Merkel PA, Furst DE, Khanna D, Emery P, Hsu VM, Silliman N, Streisand J, Powell J, Akesson A, Coppock J, Hoogen F, Herrick A, Mayes MD, Veale D, Haas J, Ledbetter S, Korn JH, Black CM, Seibold JR, Cat-192 Study Group; Scleroderma Clinical Trials Consortium: Recombinant human anti-transforming growth factor beta1 antibody therapy in systemic sclerosis: a multicenter, randomized, placebo-controlled phase I/II trial of CAT-192. Arthritis Rheum 2007, 56:323-333.

125. Li C, Yang CW, Park JH, Lim SW, Sun BK, Jung JY, Kim SB, Kim YS, Kim J, Bang BK: Pravastatin treatment attenuates interstitial inflammation and fibrosis in a rat model of chronic cyclosporine-induced nephropathy. Am J Physiol Renal Physiol 2004, 286:F46-F57.

126. Chen HC, Guh JY, Shin SJ, Lai YH: Pravastatin suppress superoxide and fibronectin production of glomerular mesangial cells induced by oxidized-LDL and high glucose. Atherosclerosis 2002, 160:141-146.

127. Hartner A, Klanke B, Cordasic N, Amann K, Schmieder RE, Veelken R, Hilgers KF: Statin treatment reduces glomerular inflammation and podocyte damage in rat deoxycorticosterone-acetate-salt hypertension. J Hypertens 2009, 27:376-385.

128. Watts KL, Spiteri MA: Connective tissue growth factor expression and induction by transforming growth factor-beta is abrogated by simvastatin via a Rho signaling mechanism. Am J Physiol Lung Cell Mol Physiol 2004, 287:L1323-L1332.

129. Grip O, Janciauskiene S: Atorvastatin reduces plasma levels of chemokine (CXCL10) in patients with Crohn's disease. PLoS One 2009, 4:e5263.

130. Grip O, Janciauskiene S, Bredberg A: Use of atorvastatin as an anti-inflammatory treatment in Crohn's disease. Br J Pharmacol 2008, 155:1085-1092.

131. Burke JP, Watson RW, Murphy M, Docherty NG, Coffey JC, O'Connell PR: Simvastatin impairs smad-3 phosphorylation and modulates transforming growth factor beta1-mediated activation of intestinal fibroblasts. $\mathrm{Br} J$ Surg 2009, 96:541-551.

132. Abe Y, Murano M, Murano N, Morita E, Inoue T, Kawakami K, Ishida K, Kuramoto T, Kakimoto K, Okada T, Narabayashi K, Umegaki E, Higuchi K: Simvastatin attenuates intestinal fibrosis independent of the anti-inflammatory effect by promoting fibroblast/myofibroblast apoptosis in the regeneration/ healing process from TNBS-induced colitis. Dig Dis Sci 2012, 57:335-344.

133. Haydont V, Bourgier C, Pocard M, Lusinchi A, Aigueperse J, Mathe D, Bourhis J, Vozenin-Brotons MC: Pravastatin Inhibits the Rho/CCN2/extracellular matrix cascade in human fibrosis explants and improves radiation-induced intestinal fibrosis in rats. Clin Cancer Res 2007, 13:5331-5340. 
134. Ruster C, Wolf G: Angiotensin II as a morphogenic cytokine stimulating renal fibrogenesis. J Am Soc Nephrol 2011, 22:1189-1199.

135. Siddesha JM, Valente AJ, Sakamuri SS, Yoshida T, Gardner JD, Somanna N, Takahashi C, Noda M, Chandrasekar B: Angiotensin II stimulates cardiac fibroblast migration via the differential regulation of matrixins and RECK. J Mol Cell Cardiol 2013, 65:9-18.

136. Bataller R, Gines P, Nicolas JM, Gorbig MN, Garcia-Ramallo E, Gasull X, Bosch J, Arroyo V, Rodes J: Angiotensin II induces contraction and proliferation of human hepatic stellate cells. Gastroenterology 2000, 118:1149-1156.

137. Corey KE, Shah N, Misdraji J, Abu Dayyeh BK, Zheng H, Bhan AK, Chung RT: The effect of angiotensin-blocking agents on liver fibrosis in patients with hepatitis C. Liver Int 2009, 29:748-753.

138. Brown NJ: Contribution of aldosterone to cardiovascular and renal inflammation and fibrosis. Nat Rev Nephrol 2013, 9:459-469.

139. Daniel C: Blocking of angiotensin II is more than blocking of transforming growth factor-beta. Kidney Int 2008, 74:551-553.

140. Couluris M, Kinder BW, Xu P, Gross-King M, Krischer J, Panos RJ: Treatment of idiopathic pulmonary fibrosis with losartan: a pilot project. Lung 2012 190:523-527.

141. Diez J, Querejeta R, Lopez B, Gonzalez A, Larman M, Martinez Ubago JL: Losartan-dependent regression of myocardial fibrosis is associated with reduction of left ventricular chamber stiffness in hypertensive patients. Circulation 2002, 105:2512-2517.

142. el-Agroudy AE, Hassan NA, Foda MA, Ismail AM, el-Sawy EA, Mousa O, Ghoneim MA: Effect of angiotensin II receptor blocker on plasma levels of TGF-beta 1 and interstitial fibrosis in hypertensive kidney transplant patients. Am J Nephrol 2003, 23:300-306.

143. De BK, Bandyopadhyay K, Das TK, Das D, Biswas PK, Majumdar D, Manda SK, Ray S, Dasgupta S: Portal pressure response to losartan compared with propranolol in patients with cirrhosis. Am J Gastroenterol 2003, 98:1371-1376

144. Hirasawa K, Sato $Y$, Hosoda $Y$, Yamamoto T, Hanai H: Immunohistochemical localization of angiotensin II receptor and local renin-angiotensin system in human colonic mucosa. J Histochem Cytochem 2002, 50:275-282.

145. Jaszewski R, Tolia V, Ehrinpreis MN, Bodzin JH, Peleman RR, Korlipara R, Weinstock JV: Increased colonic mucosal angiotensin I and II concentrations in Crohn's colitis. Gastroenterology 1990, 98:1543-1548.

146. Spencer AU, Yang H, Haxhija EQ, Wildhaber BE, Greenson JK, Teitelbaum $\mathrm{DH}$ : Reduced severity of a mouse colitis model with angiotensin converting enzyme inhibition. Dig Dis Sci 2007, 52:1060-1070.

147. Sueyoshi R, Ignatoski KM, Daignault S, Okawada M, Teitelbaum DH: Angiotensin converting enzyme-inhibitor reduces colitis severity in an IL-10 knockout model. Dig Dis Sci 2013, 58:3165-3177.

148. Lee C, Chun J, Hwang SW, Kang SJ, Im JP, Kim JS: Enalapril inhibits nuclear factor-kappaB signaling in intestinal epithelial cells and peritoneal macrophages and attenuates experimental colitis in mice. Life Sci 2014, 95:29-39.

149. Byrnes JJ, Gross S, Ellard C, Connolly K, Donahue S, Picarella D: Effects of the ACE2 inhibitor GL1001 on acute dextran sodium sulfate-induced colitis in mice. Inflamm Res 2009, 58:819-827.

150. Wengrower D, Zanninelli G, Pappo O, Latella G, Sestieri M, Villanova A, Faitelson Y, Pines M, Goldin E: Prevention of fibrosis in experimental colitis by captopril: the role of tgf-beta1. Inflamm Bowel Dis 2004, 10:536-545.

151. Wengrower D, Zanninelli G, Latella G, Necozione S, Metanes I, Israeli E, Lysy J, Pines M, Papo O, Goldin E: Losartan reduces trinitrobenzene sulphonic acid-induced colorectal fibrosis in rats. Can J Gastroenterol 2012, 26:33-39.

152. Gieling RG, Wallace K, Han YP: Interleukin-1 participates in the progression from liver injury to fibrosis. Am J Physiol Gastrointest Liver Physiol 2009, 296:G1324-G1331.

153. Liu X: Inflammatory cytokines augments TGF-beta1-induced epithelial-mesenchymal transition in A549 cells by up-regulating TbetaR-I. Cell Motil Cytoskeleton 2008, 65:935-944.

154. Diaz JA, Booth AJ, Lu G, Wood SC, Pinsky DJ, Bishop DK: Critical role for IL-6 in hypertrophy and fibrosis in chronic cardiac allograft rejection. Am J Transplant 2009, 9:1773-1783.

155. Luckett-Chastain LR, Gallucci RM: Interleukin (IL)-6 modulates transforming growth factor-beta expression in skin and dermal fibroblasts from IL-6-deficient mice. Br J Dermatol 2009, 161:237-248.

156. Ito H: IL-6 and Crohn's disease. Curr Drug Targets Inflamm Allergy 2003, 2:125-130.
157. Fichtner-Feigl S, Strober W, Geissler EK, Schlitt HJ: Cytokines mediating the induction of chronic colitis and colitis-associated fibrosis. Mucosal Immunol 2008, 1(Suppl 1):S24-S27.

158. Raghu G, Brown KK, Costabel U, Cottin V, du Bois RM, Lasky JA, Thomeer M, Utz JP, Khandker RK, McDermott L, Fatenejad S: Treatment of idiopathic pulmonary fibrosis with etanercept: an exploratory, placebo-controlled trial. Am J Respir Crit Care Med 2008, 178:948-955.

159. Corren J, Lemanske RF, Hanania NA, Korenblat PE, Parsey MV, Arron JR Harris JM, Scheerens H, Wu LC, Su Z, Mosesova S, Eisner MD, Bohen SP, Matthews JG: Lebrikizumab treatment in adults with asthma. N Engl J Med 2011, 365:1088-1098.

160. Horton MR, Santopietro V, Mathew L, Horton KM, Polito AJ, Liu MC, Danoff SK, Lechtzin N: Thalidomide for the treatment of cough in idiopathic pulmonary fibrosis: a randomized trial. Ann Intern Med 2012, 157:398-406.

161. Scaldaferri F, Vetrano S, Sans M, Arena V, Straface G, Stigliano E, Repici A, Sturm A, Malesci A, Panes J, Yla-Herttuala S, Fiocchi C, Danese S: VEGF-A links angiogenesis and inflammation in inflammatory bowel disease pathogenesis. Gastroenterology 2009, 136:585-595

162. Richeldi L, Costabel U, Selman M, Kim DS, Hansell DM, Nicholson AG, Brown KK, Flaherty KR, Noble PW, Raghu G, Brun M, Gupta A, Juhel N, Kluglich M, du Bois RM: Efficacy of a tyrosine kinase inhibitor in idiopathic pulmonary fibrosis. N Engl J Med 2011, 365:1079-1087.

163. Kugathasan S, Saubermann LJ, Smith L, Kou D, Itoh J, Binion DG, Levine AD, Blumberg RS, Fiocchi C: Mucosal T-cell immunoregulation varies in early and late inflammatory bowel disease. Gut 2007, 56:1696-1705.

164. Catania JM, Chen G, Parrish AR: Role of matrix metalloproteinases in renal pathophysiologies. Am J Physiol Renal Physiol 2007, 292:F905-F911.

165. Kim H, Oda T, Lopez-Guisa J, Wing D, Edwards DR, Soloway PD, Eddy AA: TIMP-1 deficiency does not attenuate interstitial fibrosis in obstructive nephropathy. J Am Soc Nephrol 2001, 12:736-748.

166. Clutterbuck AL, Asplin KE, Harris P, Allaway D, Mobasheri A: Targeting matrix metalloproteinases in inflammatory conditions. Curr Drug Targets 2009, 10:1245-1254.

167. Kofla-Dlubacz A, Matusiewicz M, Krzystek-Korpacka M, Iwanczak B: Correlation of MMP-3 and MMP-9 with Crohn's disease activity in children. Dig Dis Sci 2012, 57:706-712.

168. Faubion WA Jr, Fletcher JG, O'Byrne S, Feagan BG, de Villiers WJ, Salzberg B, Plevy S, Proctor DD, Valentine JF, Higgins PD, Harris JM, Diehl L, Wright L, Tew GW, Luca D, Basu K, Keir ME: EMerging BiomARKers in Inflammatory Bowel Disease (EMBARK) study identifies fecal calprotectin, serum MMP9, and serum IL-22 as a novel combination of biomarkers for Crohn's disease activity: role of cross-sectional imaging. Am J Gastroenterol 1891-1900, 2013:108.

169. Lakatos G, Hritz I, Varga MZ, Juhasz M, Miheller P, Cierny G, Tulassay Z, Herszenyi $L$ : The impact of matrix metalloproteinases and their tissue inhibitors in inflammatory bowel diseases. Dig Dis 2012, 30:289-295.

170. Meijer MJ, Mieremet-Ooms MA, van der Zon AM, van Duijn W, van Hogezand RA, Sier CF, Hommes DW, Lamers CB, Verspaget HW: Increased mucosal matrix metalloproteinase- $1,-2,-3$ and -9 activity in patients with inflammatory bowel disease and the relation with Crohn's disease phenotype. Dig Liver Dis 2007, 39:733-739.

171. Meijer MJ, Mieremet-Ooms MA, Sier CF, van Hogezand RA, Lamers CB, Hommes DW, Verspaget HW: Matrix metalloproteinases and their tissue inhibitors as prognostic indicators for diagnostic and surgical recurrence in Crohn's disease. Inflamm Bowel Dis 2009, 15:84-92.

172. Osman B, Akool el S, Doller A, Muller R, Pfeilschifter J, Eberhardt W: Differential modulation of the cytokine-induced MMP-9/TIMP-1 protease-antiprotease system by the mTOR inhibitor rapamycin. Biochem Pharmacol 2011, 81:134-143.

173. Wang S, Wilkes MC, Leof EB, Hirschberg R: Noncanonical TGF-beta pathways, mTORC1 and Abl, in renal interstitial fibrogenesis. Am J Physiol Renal Physiol 2010, 298:F142-F149.

174. Reinisch W, Panes J, Lemann M, Schreiber S, Feagan B, Schmidt S, Sturniolo GC, Mikhailova T, Alexeeva O, Sanna L, Haas T, Korom S, Mayer H: A multicenter, randomized, double-blind trial of everolimus versus azathioprine and placebo to maintain steroid-induced remission in patients with moderate-to-severe active Crohn's disease. Am J Gastroenterol 2008, 103:2284-2292.

175. Massey DC, Bredin F, Parkes M: Use of sirolimus (rapamycin) to treat refractory Crohn's disease. Gut 2008, 57:1294-1296.

176. Dumortier J, Lapalus MG, Guillaud O, Poncet G, Gagnieu MC, Partensky C, Scoazec JY: Everolimus for refractory Crohn's disease: a case report. Inflamm Bowel Dis 2008, 14:874-877. 
177. Ahmadian M, Suh JM, Hah N, Liddle C, Atkins AR, Downes M, Evans RM: PPARgamma signaling and metabolism: the good, the bad and the future. Nat Med 2013, 19:557-566.

178. Rousseaux C, Desreumaux P: [The peroxisome-proliferator-activated gamma receptor and chronic inflammatory bowel disease (PPARgamma and IBD)]. J Soc Biol 2006, 200:121-131.

179. Aoki Y, Maeno T, Aoyagi K, Ueno M, Aoki F, Aoki N, Nakagawa J, Sando Y, Shimizu Y, Suga T, Arai M, Kurabayashi M: Pioglitazone, a peroxisome proliferator-activated receptor gamma ligand, suppresses bleomycininduced acute lung injury and fibrosis. Respiration 2009, 77:311-319.

180. Wu M, Melichian DS, Chang E, Warner-Blankenship M, Ghosh AK, Varga J: Rosiglitazone abrogates bleomycin-induced scleroderma and blocks profibrotic responses through peroxisome proliferator-activated receptor-gamma. Am J Pathol 2009, 174:519-533.

181. Bertin B, Dubuquoy L, Colombel JF, Desreumaux P: PPAR-gamma in ulcerative colitis: a novel target for intervention. Curr Drug Targets 2013, 14:1501-1507.

182. Kuhn A, Haust M, Ruland V, Weber R, Verde P, Felder G, Ohmann C, Gensch $\mathrm{K}$, Ruzicka T: Effect of bosentan on skin fibrosis in patients with systemic sclerosis: a prospective, open-label, non-comparative trial. Rheumatology (Oxford) 2010, 49:1336-1345.

183. King TE Jr, Brown KK, Raghu G, du Bois RM, Lynch DA, Martinez F, Valeyre D, Leconte I, Morganti A, Roux S, Behr J: BUILD-3: a randomized, controlled trial of bosentan in idiopathic pulmonary fibrosis. Am J Respir Crit Care Med 2011, 184:92-99.

184. Johnson LA, Luke A, Sauder K, Moons DS, Horowitz JC, Higgins PD: Intestinal fibrosis is reduced by early elimination of inflammation in a mouse model of IBD: impact of a "Top-Down" approach to intestinal fibrosis in mice. Inflamm Bowel Dis 2012, 18:460-471.

185. Govani SM, Stidham RW, Higgins PD: How early to take arms against a sea of troubles? The case for aggressive early therapy in Crohn's disease to prevent fibrotic intestinal strictures. J Crohns Colitis 2013, 7:923-927.

186. Cosnes J, Cattan S, Blain A, Beaugerie L, Carbonnel F, Parc R, Gendre JP: Long-term evolution of disease behavior of Crohn's disease. Inflamm Bowel Dis 2002, 8:244-250.

187. Goodman ZD, Becker RL Jr, Pockros PJ, Afdhal NH: Progression of fibrosis in advanced chronic hepatitis C: evaluation by morphometric image analysis. Hepatology 2007, 45:886-894.

188. Duarte-Rojo A, Altamirano JT, Feld JJ: Noninvasive markers of fibrosis: key concepts for improving accuracy in daily clinical practice. Ann Hepatol 2012, 11:426-439.

189. Ryan JD, Silverberg MS, Xu W, Graff LA, Targownik LE, Walker JR, Carr R, Clara I, Miller N, Rogala L, Bernstein CN: Predicting complicated Crohn's disease and surgery: phenotypes, genetics, serology and psychological characteristics of a population-based cohort. Aliment Pharmacol Ther 2013 38:274-283

190. Jurickova I, Collins MH, Chalk C, Seese A, Bezold R, Lake K, von Allmen D, Frischer JS, Falcone RA, Trapnell BC, Denson LA: Paediatric Crohn disease patients with stricturing behaviour exhibit ileal granulocyte-macrophage colony-stimulating factor (GM-CSF) autoantibody production and reduced neutrophil bacterial killing and GM-CSF bioactivity. Clin Exp Immunol 2013, 172:455-465.

191. Maglinte DD, Bender GN, Heitkamp DE, Lappas JC, Kelvin FM: Multidetector-row helical CT enteroclysis. Radiol Clin North Am 2003, 41:249-262.

192. Al-Hawary M, Zimmermann EM: A new look at Crohn's disease: novel imaging techniques. Curr Opin Gastroenterol 2012, 28:334-340.

193. Adler J, Swanson SD, Schmiedlin-Ren P, Higgins PD, Golembeski CP, Polydorides AD, McKenna BJ, Hussain HK, Verrot TM, Zimmermann EM: Magnetization transfer helps detect intestinal fibrosis in an animal model of Crohn disease. Radiology 2011, 259:127-135.

194. Griffin N, Goh V: Functional imaging of the bowel. Abdom Imaging 2013, 38:1203-1213.

195. Schirin-Sokhan R, Winograd R, Tischendorf S, Wasmuth HE, Streetz K, Tacke F, Trautwein C, Tischendorf JJ: Assessment of inflammatory and fibrotic stenoses in patients with Crohn's disease using contrast-enhanced ultrasound and computerized algorithm: a pilot study. Digestion 2011, 83:263-268.

196. Stidham RW, Xu J, Johnson LA, Kim K, Moons DS, McKenna BJ, Rubin JM, Higgins PD: Ultrasound elasticity imaging for detecting intestinal fibrosis and inflammation in rats and humans with Crohn's disease. Gastroenterology 2011, 141:819-826.
197. Brooker JC, Beckett CG, Saunders BP, Benson MJ: Long-acting steroid injection after endoscopic dilation of anastomotic Crohn's strictures may improve the outcome: a retrospective case series. Endoscopy 2003, 35:333-337.

198. Swaminath A, Lichtiger S: Dilation of colonic strictures by intralesional injection of infliximab in patients with Crohn's colitis. Inflamm Bowel Dis 2008, 14:213-216

doi:10.1186/1755-1536-7-5

Cite this article as: Bettenworth and Rieder: Medical therapy of

stricturing Crohn's disease: what the gut can learn from other organs a systematic review. Fibrogenesis \& Tissue Repair 2014 7:5.

\section{Submit your next manuscript to BioMed Central and take full advantage of:}

- Convenient online submission

- Thorough peer review

- No space constraints or color figure charges

- Immediate publication on acceptance

- Inclusion in PubMed, CAS, Scopus and Google Scholar

- Research which is freely available for redistribution

Submit your manuscript at www.biomedcentral.com/submit
C) Biomed Central 